\title{
A comprehensive and critical overview of schistosomiasis vaccine candidates
}

\author{
Aya Al-Naseri ${ }^{1} \cdot$ Samar Al-Absi $^{1} \cdot$ Rashika El Ridi $^{1} \cdot$ Noha Mahana $^{1}$
}

Received: 16 January 2021 / Accepted: 31 March 2021/Published online: 25 April 2021

(C) Indian Society for Parasitology 2021

\begin{abstract}
A digenetic platyhelminth Schistosoma is the causative agent of schistosomiasis, one of the neglected tropical diseases that affect humans and animals in numerous countries in the Middle East, sub-Saharan Africa, South America and China. Several control methods were used for prevention of infection or treatment of acute and chronic disease. Mass drug administration led to reduction in heavy-intensity infections and morbidity, but failed to decrease schistosomiasis prevalence and eliminate transmission, indicating the need to develop anti-schistosome vaccine to prevent infection and parasite transmission. This review summarizes the efficacy and protective capacity of available schistosomiasis vaccine candidates with some insights and future prospects.
\end{abstract}

Keywords Schistosomiasis - Schistosoma · Vaccine . Candidate vaccines $\cdot$ Protective immunity

\section{Introduction}

Schistosomiasis (also referred to as bilharzia) is a parasitic disease caused by trematodes, blood flukes with a sophisticated life cycle involving an intermediate host freshwater snail, and a definitive host (humans or animals). It is a neglected tropical disease (NTD) closely linked to poverty, and infects 240 million people in 74 developing countries

Aya Al-Naseri and Samar Al-Absi have been contributed equally to this work.

Noha Mahana

nmahana@sci.cu.edu.eg

1 Zoology Department, Faculty of Science, Cairo Univesity, Giza 12613, Egypt in the tropics and sub-tropics, and 779 million, mostly children are at risk (Loverde 2019; Chisha et al. 2020; Kura et al. 2020). The burden of schistosomiasis in 2016 was estimated at 2543364 disability-adjusted life years (DALYs) (World Health Organization 2019). Most of human infections are caused by Schistosoma haematobium (endemic in Africa and Middle East), S. mansoni (in Central South America, Africa, and Middle East), and $S$. japonicum (in Eastern Asia) (Di Bella et al. 2018). Schistosoma mansoni and S. japonicum are responsible for chronic hepatic and intestinal fibrosis while S. haematobium causes fibrosis in the urinary tract (McManus and Loukas 2008).

There is interrelation between schistosome infection and host immune responses, as worms can live for several decades in contact with products of immune responses circulating in the blood. The study of this interaction can help in disease control by searching for new drug or developing a vaccine (Fonseca et al. 2012). Praziquantel (PZQ, pyrazino-isoquinolone) is the only readily effective drug widely used for the treatment of the three main parasites causing human schistosomiasis. It has good pharmacologic properties such as it can be given as a single oral dose, is usually well tolerated, with low cost and limited side effects (LoVerde 2019). However, schistosome chemotherapy still has some limitations (Kittur et al. 2017; Wiegand et al. 2017). Praziquantel-based mass drug administration programs require several rounds of treatment. Additionally, only a fraction of the target population receives the drug, because preventive chemotherapy for schistosomiasis was found to be still required in 2018 in 52 countries and was received by 19.1 out of 104.8 million adults $(18.2 \%)$ and 76.2 million out of 124.4 million children attending school (61.2\%) (World Health Organization 2019). The coverage of the numerous children that do not 
attend school in poor, rural endemic communities and preschool age children is certainly much lower. These data explain ntensity of infection and morbidity were reduced in several countries, but prevalence and DALYs remain dramatically high (Deol et al. 2019). Indeed, the World Health Organization recommended periodic PZQ treatments only as a short-term measure for the control of morbidity (World Health Organization 2019). Therefore, vaccines, alone or combined with chemotherapy, present the best strategy for long-term control of schistosomiasis (Ross et al. 2002, 2015).

Disappointingly, up to date there is no commercial vaccine available against any of the human schistosomes emphasizing the need for continued efforts towards achieving this elusive goal (Hewitson and Maizels 2014; McManus et al. 2020). Many groups have made recommendations about which vaccine candidate should be developed against schistosomiasis, suggesting that an effective prophylactic vaccine should reduce the morbidity (Siddiqui and Siddiqui 2017), as well as reduce adult worm burden and egg excretion rates by $75 \%$ in immunized individuals (Molehin 2020). The current review will present a comprehensive overview on the efficacy of experimental, but unlicensed, vaccines against schistosomiasis in both humans and animals, delineating new formulations of the present candidates or future vaccine discovery.

The major reason for schistosomiasis spread is the inability of the immune system elements to recognize and eliminate migrating larvae and adult worms. Radiation-attenuated (RA) schistosome larvae vaccine has shown capability to induce consistently high protective immune (Th1 and Th2) responses against challenge infection in laboratory animals (Coulson 1997; Street et al. 1999), and revealed that a schistosomiasis vaccine is a real goal, despite that multiple concerns regarding this approach make it unsuitable for use in humans (Coulson 1997). Furthermore, these promising results paved the way for the discovery of different vaccine candidate antigens, irradiated cercariae vaccine-associated S. mansoni antigens (IrV) (Soisson et al. 1992, 1993), fatty acid-binding protein (FABP, Sm14), paramyosin, calpain large subunit (Smp80), superoxide dismutase (SOD), glutathione-S-transferase (GST), glyceraldehyde 3-phosphate dehydrogenase (SG3PDH), cysteine peptidases (CPs) (Othman and El Ridi 2014; Pearson et al. 2015), the surface membrane antigen, Sm23 (Harn et al. 1985; Reynolds et al. 1992; Koster et al. 1993) and many other antigens (Table 1). Despite the discovery and publication of numerous promising vaccine antigens candidates, only four have shown promises in human clinical trials and were chosen due to access, and protective immunity potential in non-human primates. These recombinant antigens include $S$. haematobium 28-kD GST (rSh28GST) (Boulanger et al. 1999; Johnson et al. 2003), S. mansoni 14-kDa ( $\mathrm{Sm14}$ ) (Moser et al. 1991), S. mansoni tetraspanin, a 9-kDa surface antigen, Sm-TSP-2, (Smyth et al. 2003), and S. mansoni calpain (Sm-p80) (Siddiqui et al. 1993).

Recently, many of the above-mentioned antigen candidates, including TSP-2, Sm23, GST, Sm29 and calpain, were identified in extracellular vesicles (EVs) of schistosome adult worms, (Kifle et al. 2020a). Extracellular vesicles are membrane-surrounded vesicles that are continually secreted by different types of cells and play an important role in removing unnecessary cell components, cell-cell communication, and inter-cellular transfer of their mRNA, microRNA (miRNA), lipid and protein cargo (Pluchino and Smith 2019). Such close host- parasite interactions suggest EVs may play a role in protection against schistosomiasis (Kifle et al. 2020a; b), allowing the host immune effectors, namely antibodies, to interact with otherwise inaccessible worm cytosolic, tegumental, and surface membrane antigens, and activate immune cells capable of chasing and harming the parasite (El Ridi and Tallima 2013a; b).

\section{Vaccine candidates in clinical trials}

\section{8 kDa glutathione S-transferase}

Schistosoma haematobium $28 \mathrm{kDa}$ glutathione S-transferase (Sh28GST) vaccine is expressed in the tegument and sub-tegument of adult (Taylor et al. 1988) and larval (Balloul et al. 1985) schistosomes, and is a predominant ESP (Knudsen et al. 2005; Hansell et al. 2008; El Ridi and Tallima 2009, 2013a; El Ridi et al. 2017). It has a main role in fatty acid metabolism and prostaglandin D2 synthesis, and may contribute to the parasite immune evasion (Tebeje et al. 2016). Several studies were made using the recombinant protein (expressed in Saccharomyces cerevisiae) in rodents, primates and cattles (Johnson et al. 2003; Capron et al. 2005; Baiocco et al. 2006). The results showed partial protective effect against schistosome infection, significant reduction of the worm burden (40-60\%), in addition to significant reduction in female worm fecundity and eggs viability (Boulanger et al. 1991; Xu et al. 1991; Bushara et al. 1993; McNair et al. 1993; Capron et al. 1994). Notably, recombinant $S$. haematobium glutathione S-transferase (rShGST) vaccine mediated high levels of protection associated with intense specific $\operatorname{IgG}$ and $\operatorname{IgA}$ antibody responses in baboons and patas monkeys (Boulanger et al. 1991, 1995, 1999). Phase 1 trial was designed to investigate the safety and tolerability of two or three subcutaneous injections of $100 \mu \mathrm{g}$ rSh28GST antigen with Alum as adjuvant in young, healthy, Caucasian male adult volunteers. The vaccine was perfectly safe for use in adults 
Table 1 Major schistosome vaccine candidates
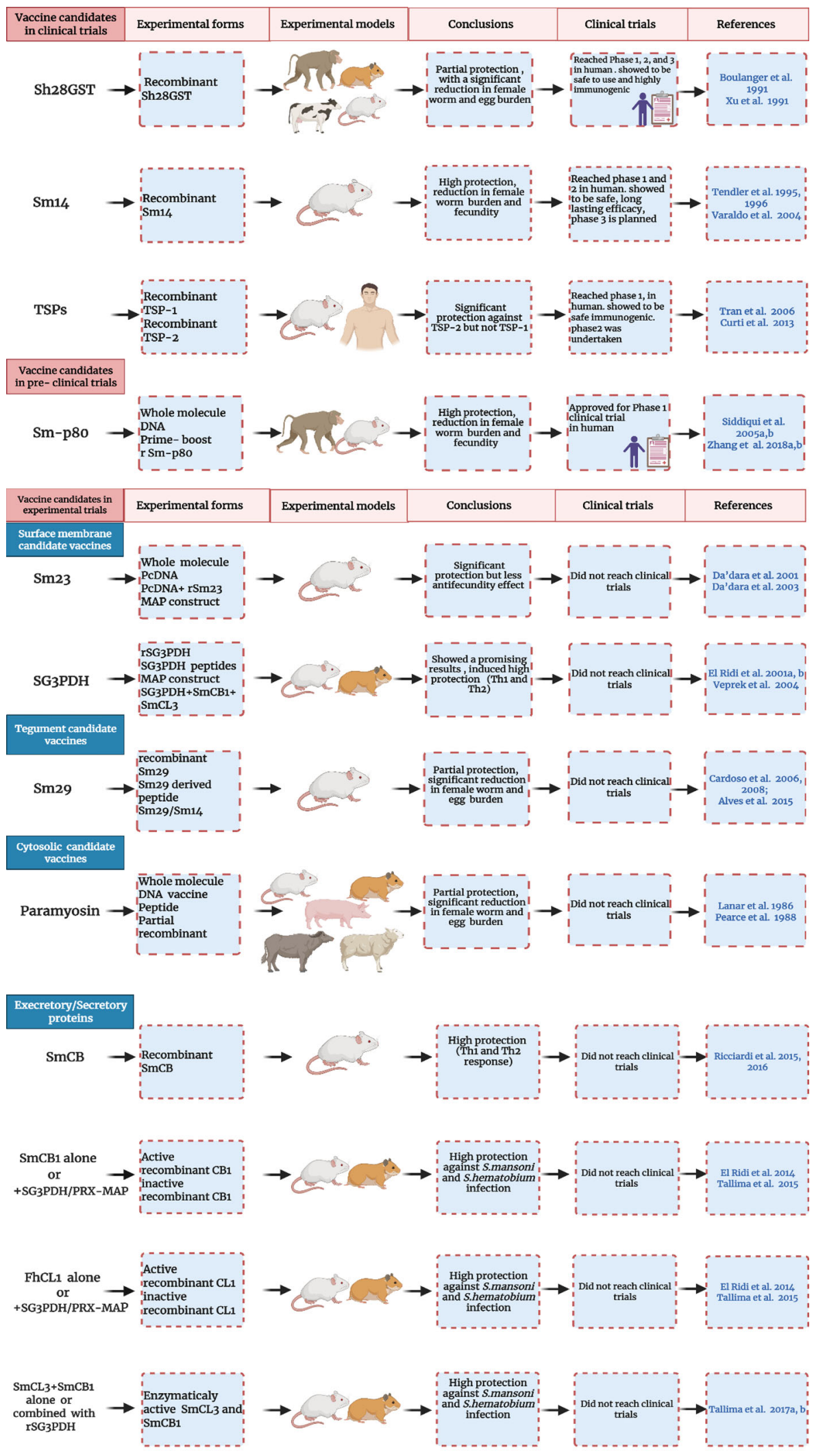

Created in BioRender.com bio

Sm Schistosoma mansoni, Sh Schistosoma hematobium, Fh Fasciola hepatica, G3PDH, glyceraldehyde 3-phosphate dehydrogenase, GST glutathione-S-transferase, TSPs tetraspanin; $C B$, cathepsin B, $C L$ cathepsin L, PRX Peroxidase, MAP Multiple antigen peptide 
and highly immunogenic, inducing interleukin (IL)-5 and IL-13, absence of IgE, and predominance of IgG1 antibodies capable of inhibiting the enzymatic activity of the immunogen (Riveau et al. 2012). Safety, tolerability and immunogenicity of the vaccine were also demonstrated in adults and children residing in endemic regions (Mo et al. 2014). rShGST is the only schistosomiasis antigen that has reached Phase 3 clinical trials. In Phase 3, 250, 6-9 yearsold Senegalese children, were cured of schistosome infection and randomized to receive three subcutaneous injections of either rSh28GST/Alhydrogel (Bilhvax group) or Alhydrogel alone (control group) with four-week intervals, and then a booster one year after the first injection. The vaccine protective capacity was evaluated by recurrence of natural infection within approximately two years following PZQ treatment on week 44, 8 weeks before the booster injection (on week 52). Children immunized with rSh28GST showed elevated levels of specific IgG1, IgG2, and IgG4 antibody but a lack of IgG3 and IgA isotypes. In human populations, acquired immunity is linked with IgG3 and IgA antibodies to Sh28GST. Failure in achieving protection against urinary schistosomiasis might be due to the antibody isotype issue (Riveau et al. 2018) or to the confounding impact of the PZQ treatment before the first and last immunization (Alsallaq et al. 2017).

\section{Schistosoma mansoni $14 \mathrm{kDa}$ fatty acid binding protein}

Schistosoma mansoni $14 \mathrm{kDa}$ (Sm14) fatty acid binding protein (FABP) is located in the basal lamella of the tegument and gut epithelium (Brito et al. 2002; Tendler and Simpson 2008). Schistosomes lack an oxygen-dependent pathway for the synthesis of fatty acids and sterols. Hence, they are entirely dependent on the host by using Sm14 to absorb and transport fatty acids from the host (Tendler and Simpson 2008; Tebeje et al. 2016). Sm14 is, hence, considered a good target for development of an effective vaccine against schistosomiasis. Its recombinant form (rSm14) showed significant protective immunity against $S$. mansoni in outbred Swiss mice and New Zealand White rabbits (60-95\%). In addition, it induced immune cross protection against Fasciola hepatica infection. So, it is potentially used against different infections and has great appeal in terms of human and animal health (Tendler et al. 1995, 1996; Tendler and Simpson 2008; Santini-Oliveira et al. 2016). Otherwise, outbred Swiss mice immunized once with rSm14-Bacillus Calmette-Guerin (rSm14-BCG) and challenged with $S$. mansoni cercariae showed reduction (48\%) in worm burden that was analogous to that obtained by vaccination with $\mathrm{rSm} 14$ protein (Varaldo et al. 2004).

Hence, the antigen was allowed to move forward to clinical trials to assess its safety and immunogenicity on humans. In Phase 1a and 1b trials (2011-2014), rSm14 was formulated with glucopyranosyl lipid adjuvant (GLA) adjuvant in an oil-in-water emulsion and used to immunize 20 male and 10 female volunteers from a non-endemic area for schistosomiasis in Rio de Janeiro state, Brazil. Results showed no adverse events related to the vaccine, which elicited significant increase in Sm14-specific total $\mathrm{IgG}$, with no IgE observed at any time, and stimulated both Th1 and Th2 cytokines (Tendler et al. 2015; Santini-Oliveira et al. 2016). Accordingly, the results supported this product as a safe, strongly immunogenic vaccine against schistosomiasis, and paved the way for follow-up phase 2 trials (2015-2017). In phase 2a trial, rSm14 vaccine was safe with long lasting immunogenicity when administrated to 30 male adults from endemic area for both $S$. mansoni and S. haematobium in Senegal River Basin (Tendler et al. 2018). Accordingly, Phase $2 b$ and phase 3 trials are planned (McManus et al. 2020).

https://clinicaltrials.gov/ct2/show/NCT03041766

https://clinicaltrials.gov/ct2/show/NCT03799510

\section{Tetraspanins}

A family of tetraspanins (TSPs) is highly expressed in the $S$. mansoni tegument membranocalyx, and outermost membrane of the intra-mammalian stages of the parasite, apparently accessible to the immune system elements; the portion readily exposed to the host immune system is the extracellular loop (van Balkom et al. 2005; Braschi et al. 2006; Braschi and Wilson 2006; Wilson 2012). Schistosoma mansoni TSPs (Sm-TSP-1 and Sm-TSP-2) play important roles in tegument stability, development, or maturation (Tran et al. 2006, 2010). IgG1 and IgG3 (no $\mathrm{IgE})$ antibodies isolated from naturally immune individuals recognized TSP-2, not TSP-1, when compared to antibodies from chronically infected or naïve individuals (Correa-Oliveira et al. 1989, 2000; Tran et al. 2006; Loukas et al. 2007). As well, TSP-2 conferred high level of protection in mice with generation of $\mathrm{IgG}$ antibodies, which correlated positively with protective immunity in naturally resistant people. Therefore, efficacy trials have focused on the TSP-2 antigen reflecting its use as schistosomiasis vaccine (Pearson et al. 2015; Hotez et al. 2019).

Vaccination of $\mathrm{CBA} / \mathrm{CaH}$ mice with $\mathrm{rSm}-\mathrm{TSP}-2$ formulated with adjuvant conferred high levels of protective immunity against challenge infection with $S$. mansoni, characterized by reduction of $57 \%$ and $64 \%$ in adult worm and liver egg burdens, respectively. While immunization with rTSP-1 resulted in lesser protective immunity than rTSP- 2 represented by $34 \%$ and $52 \%$ reduction in adult worm and liver egg burdens, respectively (Tran et al. 2006). Along with ShGST and Sm14, TSP-2 has reached the clinical trial phase 1 and showed that the TSP-2/alum 
(Al) hydrogel in formulation with or without an aqueous GLA formulation (GLA-AF) was well tolerated and safe to use for humans when administrated to healthy young adults who reside in non- $S$. mansoni-endemic area (Keitel et al. 2019). Furthermore, phase $1 \mathrm{~b}$ dose-escalation study has been undertaken to assess the safety and immunogenicity of Sm-TSP-2 with or without AP 10-701 (new nomemclature of GLA-AF) in healthy Ugandan adults (Keitel et al. 2019) https://clinicaltrials.gov/ct2/show/NCT03910972.

Recently, TSPs were found to be localized in adults $S$. mansoni and S. hematobium tegument vesicles, not on the surface membrane (Schulte et al. 2013; Sotillo et al. 2015), supporting a mechanism of action via release in EVs (i.e. ESP) (Sotillo et al. 2016; Samoil et al. 2018; Kifle et al. 2020a; Mekonnen et al. 2020). The study of Mekonnen et al. (2020) reported that ShTSP-2 conferred a highly significant protection against heterologous challenge ( $S$. mansoni) model of infection. However, it is not clear how the ability of anti-TSP antibodies to block vesicle uptake by host target cells explains the potential of TSPs as promising anti-fluke vaccine (Kifle et al. 2020b).

\section{Vaccine candidate in pre-clinical trials}

\section{Sm-p80}

Sm-p80 is the large subunit (heavy chain) of the S. mansoni calcium-activated neutral protease, calpain (Siddiqui and Siddiqui 2017), immunolocalized in different schistosome life stages at the inner membrane of the tegument and underlying musculature (Braschi and Wilson 2006). It is an excretory-secretory product (ESP) released upon larvae skin invasion and during migration in the lung (Knudsen et al. 2005; Hansell et al. 2008; El Ridi and Tallima 2009, 2013a; El Ridi et al. 2017), and was predominant in adult worms-derived EVs (Kifle et al. 2020a). Calpain helps the worm escape the immune response by surface membrane turnover, by degradation of fibronectin, and inhibiting blood clot formation around the worm (Siddiqui et al. 1993; Kumagai et al. 2005; Wang et al. 2017). Despite calpain location on the inner side of the surface membrane of schistosome, it represents a target for vaccine development. It has been tested for efficacy in different forms, like prime boost, recombinant (r), or DNA based forms and showed significant protection capacity, had remarkable efficacy in fecundity reduction, and reduced the egg-induced pathology with transmission blocking potential in rodents and baboons (Siddiqui et al. 1993; Siddiqui et al. 2003a, b, 2005a; Ahmad et al. 2009a, b, c; Zhang et al. 2010, 2014; Karmakar et al. 2014a; Le et al. 2018). Of note, Sm-p80 ortholog expressed in the tegument of $S$. japonicum and S. haematobium adult worms significantly conferred cross-species protection in rodents and baboons against $S$. mansoni, S. japonicum, and $S$. haematobium infections (Zhan et al. 2014; Karmakar et al. 2014b, c; Molehin et al. 2017).

Findings in both mice and baboons have confirmed that Sm-p80 vaccine-based protection involves antibodies and type 1 cytokines (Torben et al. 2011). Immunization of C57BL/6 mice and olive baboons with Sm-p80 combined with GLA adsorbed on aluminum hydroxide (Smp80 + GLA-alum) resulted in worm burden reduction by 39-44\%, and production of Sm-p80-specific total IgG and IgG subtypes (IgG1, IgG2a, IgG2b and IgG3), with an elevation in Th1 cytokines IFN- $\gamma$, IL- 2 and TNF- $\alpha$ (Zhang et al. 2018a). Furthermore, in double-blind preclinical trial, olive baboons immunized with Sm-p80/GLA-SE (GLA suspended in a stable squalene-based oil-in-water emulsion, SE) showed considerable reduction in adult female worms $(93.4 \%)$ and remarkable reduction in tissue egg load $(89.9 \%)$. Of note, a considerable decrease in schistosome egg excretion in feces of vaccinated baboons, combined with more than $80 \%$ reduction in egg maturation and viability documented the parasite transmission-blocking potential of the vaccine (Zhang et al. 2018b). Immunization with Smp80 + CpG-oligodeoxynucleotide (CpG-ODN) adjuvant reduced liver egg burdens by $38.0 \%$ and egg load in small and large gut by $72.2 \%$ and $49.4 \%$, respectively, in baboons. Furthermore, significant production of Sm-p80specific antibodies was detected in immunized baboons (Siddiqui et al. 2018). These promising results supported Sm-p80 vaccine has now been approved for Phase 1 clinical trials to begin in early-mid 2021 (Molehin 2020; Tsuji 2020).

Sm-p80 protection was attributed to ADCC, which is impossible as the molecule is not located on the apical lipid layer of the worm surface membrane, and even so, would not be accessible by antibodies (Zhang et al. 2001; Ohta et al. 2004; Ahmad et al. 2009a, b, c; Zhang et al. 2010; Siddiqui and Siddiqui 2011; Torben et al. 2012; Karmaker et al. 2014a). The Sm-p80 immunogen may interact with vaccine-induced specific antibodies, leading to activation of effector cells and release of inflammatory mediators. Calpain was recently found to be enriched in EV (Kifle et al. 2020a), and when it interacts with antibodies, calpain/ antibody complexes can be internalized by the host and may enhance the production of arachidonic acid, and immune cells activation and trafficking (Kifle et al. 2020b). 


\section{Vaccine candidates in experimental trials}

\section{Surface membrane candidate vaccines}

\section{$\operatorname{Sm} 23$}

Surface membrane $23 \mathrm{kDa}(\mathrm{Sm} 23)$, an integral membrane protein (Rogers et al. 1988), was first identified by Harn and his colleagues as the target of a protective monoclonal antibody. It has been shown to confer protection in naive mice (Harn et al. 1985), and classified as a member of the 'tetraspanin' trans-membrane protein family (Wright et al. 1990; Lebel-Binay et al. 1995). Sm23 is exposed on the apical membrane of parasite (Wright et al. 1991); however, in low quantity (Braschi and Wilson 2006), and expressed in the adult tegument (Harn et al. 1985; Oligino et al. 1988).

Efforts have been made to develop an effective vaccine using Sm23 in plasmid DNA (pcDNA), multiple antigenic peptides (MAPs), and recombinant (r) vaccines constructs. High levels of protection were achieved upon Sm23 use in MAP form, based on B and T cell epitopes (Reynolds et al. 1992; Harn et al. 1995). Priming and boosting of C57BL/6 mice with Sm23-pcDNA elicited production of $\mathrm{IgG} 2 \mathrm{a}$ and IgG1 antibodies showed statistically significant reduction of 21-44\% in worm and egg burdens (Da'Dara et al. 2001); the number of eggs recovered per worm pair did not differ significantly, showing that the Sm23-pcDNA vaccine has no additional anti-fecundity effect. Sm23-pcDNA immunization of C57BL/6 mice followed by boosting with rSm23 formulated with alum did not result in significant reduction in worm burdens, despite it induced higher antiSm23 antibodies (IgG1) level than Sm23-pcDNA alone. In addition, mice primed and boosted with $\mathrm{rSm} 23$ formulated in alum were also not protected from challenge infection, likely because the protective vaccination using $\mathrm{Sm} 23$ is associated with a Th1 immune response (Da'Dara et al. 2003). In a subsequent study, immunization of C57BL/6 mice with Sm23 DNA elicited only $34 \%$ protection despite induction of pecific antibody responses that were predominately of the IgG2a and IgG2b isotypes (Ganley-leal et al. 2005).

A more recent study revealed a limited number of conformational epitopes on $\mathrm{Sm} 23$ and other tegmental proteins have the ability to elicit mouse, rat and human production of serum antibodies against S. mansoni infection, but they never influenced schistosomula or adult worm survival suggesting that there is a need to re-evaluate host immune responses to many schistosome antigens (Krautz-Peterson et al. 2017). El Ridi and Tallima (2013a; b) explained that surface membrane antigens may be immunogenic, inducing $\mathrm{T}$ and $\mathrm{B}$ cell responses, but antibodies are unable to get access to surface membrane antigens and activate antibody-dependent complement or cell-mediated (ADCC) cytotoxicity. It is remarkable that vaccination with a protein at the host-parasite interface induced only limited reduction in challenge infection parameters. It is because surface membrane antigens are hindered by a sphingomyelin (SM)-based hydrogen-bond network protecting the larval, developing, and adult worms from the host immune effectors (El Ridi and Tallima 2006; Keating et al. 2006; Tallima and El Ridi 2008; Migliardo et al. 2014; El Ridi et al. 2017). Then molecules at the apical surface are not accessible to antibody binding in healthy worms.

The mechanism behind Sm-23-mediated protection may be explained by their presence as ESP or in EVs, exosomelike, $120 \mathrm{k}$ pellet vesicles and microvesicle-like, $15 \mathrm{k}$ pellet vesicles, found to be a reservoir of different vaccine candidates such as, TSPs Sm23, Sm-TSP-1, and Sm-TSP-2 (Kifle et al. 2020a). Recombimamt Sm23 and other TSPs extracted from adult $S$. haematobium worms were shown to induce significant protection characterized by reduction in liver $(47 \%, 38 \%$ and $41 \%)$ and intestinal $(47 \%, 45 \%$ and $41 \%$ ) egg burdens against challenge infection with $S$. mansoni. These results reflect that EVs surface proteins can be used as anti-schistosome vaccine candidates (Mekonnen et al. 2020), provided they evoke critical responses needed for optimal vaccine efficacy (Ganley-leal et al. 2005).

\section{Glucose transporter proteins}

Adult schistosomes obtain their glucose from the host blood. Two glucose transporter proteins (GTPs) have been identified in the tegument of S. mansoni, SGTP 1 and 4 antigens (Krautz-Peterson et al. 2010; You et al. 2014). SGTP1 is expressed in the tegmental basal membrane and other tissues of different life stages of the schistosome, whilst SGTP4 is present in the host interactive, apical tegmental membranes (Swain et al. 2011; You et al. 2014). SGTP4 facilitates the import of glucose from the host bloodstream into the tegument. SGTP1 and SGTP4-suppressed parasites are unable to import glucose, providing evidence for the importance of these SGTPs in importing exogenous glucose, and then affecting parasite development in the mammalian host (Krautz-Peterson et al. 2010; Swain et al. 2011; You et al. 2014). Peptide or recombinant form of SGTP4 conjugated with complete (CFA) or incomplete (IFA) Freund's adjuvant showed no protection against challenge infection with $S$. mansoni in outbred CD1 mice despite specific cellular and humoral immune responses (Mahana 2007). The reason is due to the explanation mentioned above, namely that no apical membrane antigen is accessible to host antibodies. Limited SM hydrolysis allows nutrient $<400 \mathrm{kDa}$ entry but not host 
immune effectors. Another reason lies in GTPs molecule structure (Fig. 1), and poor immunogenicity (Tucker et al. 2018). Such 12 transmembrane domain, hydrophobic molecules, even within EV, are immediately endocytosed by antigen presenting cell (APC), and their conformational epitopes poorly recognized by B cells. Nevertheless, due to its critical importance for schistosomes' survival, SGTP4 is now considered a major target for schistosomiasis chemotherapy (Adekiya et al. 2020).

\section{Glyceraldehyde 3-phosphate dehydrogenase}

Glyceraldehyde 3-phosphate dehydrogenase (G3PDH) is a cytosolic antigen. Yet, it was readily detected on the surface of S. mansoni $3 \mathrm{~h}$ in vitro schistosomula (GoudotCrozel et al. 1989), lung-stage schistosomula (Tallima and El Ridi 2008; Pirovich et al. 2019, 2020), among adult worms surface membrane-associated molecules, and in larval and adult worms excretory-secretory products (ESP) (Braschi and Wilson 2006; Sotillo et al. 2015). Indeed, schistosome G3PDH (SG3PDH) is considered a prominent moonlighting protein. Moonlighting proteins comprise a subset of multifunctional proteins in which one protein exhibits more than one physiologically critical function (Huberts and Van der klei 2010).

Excretory secretory SG3PDH is considered as one of the major vaccine candidates against schistosomiasis (McManus and Loukas 2008), and plays a role in the prevention of reinfection (El Ridi et al. 2001a, 2004; b). However, due to its high homology (72.5\%) to human G3PDH the whole parasite proteins may not be used as a vaccine for fear of inducing autoimmune responses. Therefore, it is better to select SG3PDH derived-peptides sharing the lowest homology to those of human, and the peptides were selected for devising a safe synthetic peptide-based vaccine (El Ridi et al. 2001a). These peptides were examined using serum and lymphocytes from humans resistant to reinfection with $S$. mansoni or S. haematobium after treatment with PZQ of previous infection and from BALB/c and C57BL/6 mice immunized with recombinant $\mathrm{rSG} 3 \mathrm{PDH}$ (rSG3PDH). The results revealed that SG3PDH-derived peptides possess human and murine $\mathrm{T}$ - and $\mathrm{B}$-cell determinants and immune responses to the peptides correlate with resistance to schistosomiasis infection (EL Ridi et al. 2001a).

Linear peptides in MAP or dipeptidic-MAP (D-MAP) constructs induced Th1 and Th2 immune responses in mice but with different protective levels (Tallima et al. 2003; El Ridi et al. 2004; Veprek et al. 2004), supporting the evidence that both Th1 and Th2 immune responses are required for protective immunity against schistosomiasis (McManus 1999; El Ridi 2002; Al-Sherbiny et al. 2003). The failure in developing the SG3PDH vaccine was corrected when SG3PDH was combined with type 2 cytokines or type 2 immunity-inducing cysteine peptidases. The results showed highly significant $(P<0.0001)$ reduction $(62-78 \%)$ in worm burden, and copious production of $\operatorname{IgM}$, IgG1, and IgA specific antibodies, and IL-4 and IL-5 cytokines in outbred CD-1 mice (El Ridi and Tallima 2013a, b).

\section{Tegument candidate vaccines}

\section{Superoxide dismutase}

Superoxide dismutase (SOD) antioxidant enzyme is a candidate vaccine against schistosome infection, as it has an important role in schistosome immune evasion (Shalaby et al. 2003). It has a defensive role against tegument attack (lipid peroxidation) in adult worms that result from the release of reactive oxygen species (ROS) by host cells (LoVerde 2004; Chiumiento and Bruschi 2009). Yet, it is expressed with high levels in the adult worms (the least susceptible to immune elimination) and low levels in the larval stages (the most susceptible to immune elimination) (LoVerde et al. 2004). There are two SOD in S. mansoni,

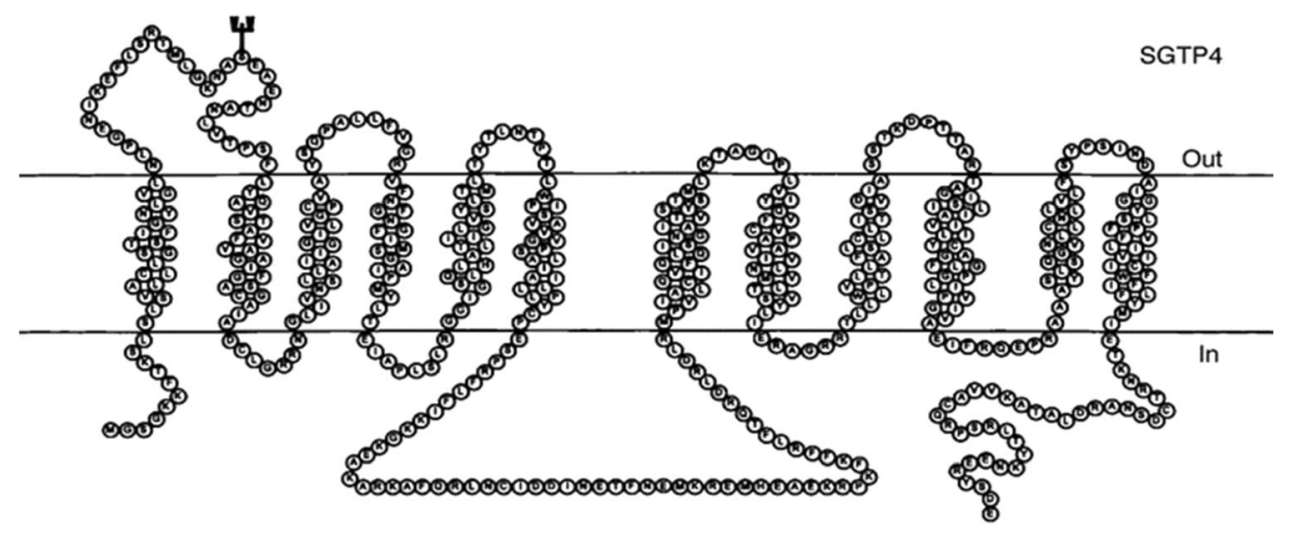

Fig. 1 Schistosome glucose transporter protein 4 structure (Skelly et al. 1998) 
one cytosolic $\mathrm{Cu} / \mathrm{Zn}$ dependent (CT-SOD) and the second extracellular or membrane-associated which contains one peptide signal (SP-SOD) (Mkojii et al. 1988; Nare et al. 1990). Both forms are present in the tegument and the intestinal epithelium of the adult stage, whereas the extracellular form is localized also in the membranes of parenchymatous cells and cellular organelles (Hong et al. 1992; Mei and LoVerde 1997).

Immunization of $\mathrm{BALB} / \mathrm{c}$ mice with pcCT-SOD led to significantly decreased worm burden $(42.8,35.9$ and $38.0 \%$ ) in three independent experiments, and indicated that pcCT-SOD activates Th1 rather than Th2 immune responses (Cook et al. 2004). Immunization of BALB/c and C57BL/6 mice with DNA based SmCT-SOD and S. mansoni glutathione peroxidase (SmGPX) then challenged with $S$. mansoni cercariae resulted in significant reduction in worm burden (44-60\% and 23-55\%, respectively) in six independent experiments. Additionally, SmCT-SOD and SmGPX DNA-based vaccine was consistently conferring greater than $40 \%$ protection, which is the World Health Organization minimum requirement (Shalaby et al. 2003; LoVerde et al. 2004; Tebeje et al. 2016). Similarly, a protective effect of SOD against schistosomiasis in olive baboons was revealed by Carvalho-Queiroz et al. (2015), whereby animals primed with naked DNA of SOD forms and GPX and boosted with the respective recombinant antioxidant proteins encapsulated in polylactic acid (PLA) microspheres, were able to stimulate both humoral and cellular responses (including cytokines and chemokines). This resulted in a reduction in worm numbers, and a pronounced anti-pathology effect compared to control animals (Carvalho-Queiroz et al. 2015; Tebeje et al. 2016).

\section{S. mansoni 29 kDa protein}

Sm29 is a glycosylphosphatidylinositol (GPI) integral protein localized in the tegument of mammalian adults and lung-stage schistosomula and absent in cercariae indicating that this antigen plays a role in helping the parasite to adapt to the new environment in mammalian hosts (Braschi et al. 2006; Cardoso et al. 2006a, 2008; Castro-Borges et al. 2011; Sotillo et al. 2015). Sm29 was suggested to play a role in parasite evasion of immune response by interaction with human protein CD59, which inhibits membrane attack complex (MAC) and would help the schistosome to disable immune responses (Bear et al. 2018). As well, it is considered as an immunoregulatory molecule, which regulates inflammatory mucosal diseases (leishmaniasis and asthma) (Oliveira et al. 2016). It was recently identified in $120 \mathrm{k}$ and $15 \mathrm{k}$ EVs of the tegument (Kifle et al. 2020a). Since Coulson and Wilson (1997) have suggested regarding vaccination with irradiated cercariae that the lung is the main site of parasite elimination. Sm29 localization on schistosomula tegument suggests it as a good target for vaccine development against schistosomiasis. Moreover, $\mathrm{Sm} 29$ ortholog is present in ESP of $S$. japonicum with more than 50\% homology, suggesting that Sm29 might also be effective against S. japonicum (Cardoso et al. 2006b). Immunization of C57BL/6 and TLR4 KO mice with rSm29 induced Th1-Th2 type of immune responses characterized by high levels of IgG1 and IgG2a antibodies and IFN-c, tumor necrosis factor (TNF)- $\alpha$, and IL-12 cytokines associated with significant reduction in parasite burden $(51 \%)$ and pathology (Cardoso et al. 2008). More importantly, rSm29 has shown significant protection $(26-48 \%)$ in previously $S$. mansoni infected $\mathrm{BALB} / \mathrm{c}$ mice, treated with PZQ. Protection was characterized by elevated levels of IgG, IgG1, IgG2a, and IgE antibodies, IL-2, IFN- $\gamma$, IL-17, IL-4, and CD4 + central memory $\mathrm{T}$ cells (Alves et al. 2015). Of note, individuals living in areas endemic for schistosomiasis, the resistance to $S$. mansoni infection and reinfection is associated with the production of $\operatorname{IgG1}$ and IgG3 specific to Sm29 (Cardoso et al. 2006a). Differences observed in antibody titers between the rSm29-immunized group, that did not develop protective immunity and $S$. mansoni infected and PZQ-treated/rSm29 group, which developed a protective immunity, resided in an increased titer of $\operatorname{IgG}$ and decreased titer of IgG1. These results suggest that other IgG isotypes may be associated with the protection induced by this vaccine formulation (Alves et al. 2015). Alongside, to improve immunogenicity and safety, rSm29 was linked to gold nanorods carrier directly or by cysteamine functionalization and examined against $S$. mansoni challenge infection in C57BL/6 mice. The results showed a remarkable protection level $(34 \%)$ characterized by Th1 immune response parameters (Assis et al. 2018). In another study, Sm29 was formulated with alum or monophosphoryl lipid A adjuvant (MPLA) then administered to BALB/c mice reinfected with $S$. mansoni. Sm29-alum induced partial protection against reinfection, reduced worm burden by $29-37 \%$ while Sm29-MPLA failed to reduce worm burden, indicating that Sm29-alum can effectively protect against $S$. mansoni reinfection in mice (Alves et al. 2018).

The fusion of Sm29 with Sm14, designated as Sm14/29 alone or combined with polyinosinic-poly cytidylic acid [poly (I:C)] adjuvant elicited significant reduction of adult worm burden by $48.4 \%$ and $44.7 \%$, liver egg burden by $82.8 \%$ and 73.5 , intestinal egg count by $72.8 \%$ and $76.6 \%$, respectively, in Swiss albino mice (Mossallam et al. 2015; Eyayu et al. 2020). Similarly, Sm29 fused with Sm-TSP-2 resulted in reduction (22-35\%) of worm burden, with an elevated level of IgG1 and IgG2 antibodies, IFN- $\gamma$ and TNF- $\alpha$ in C57BL/6 mice (Pinheiro et al. 2014). These results suggest the multi-antigens fusion proteins might be potential vaccine candidates. More recently, a multi 
epitope-based vaccine containing predicted epitopes from Sm14, Sm21.7, Sm23, Sm29, Smp80, Sm-CB, and SMTSP-2 antigens was developed. Immunoinformatic analysis demonstrated that the vaccine has a high potential to stimulate $\mathrm{T}$ and B-cell mediated immune responses, and indicated that a multi epitope-based vaccine can be utilized for prophylactic or therapeutic aims in response to the infection caused by S. mansoni (Rahmani et al. 2019).

\section{Insulin receptors}

Schistosomes are unable to synthesize insulin (Affholter et al. 1988); instead, they depend on host insulin for fecundity and growth. Insulin $(5808 \mathrm{Da})$ regulates glucose uptake, improves the viability of schistosomes, and promotes the metabolism and development of adult worms (Vicogne et al. 2004; Saule et al. 2005; Ahier et al. 2008; You et al. 2009). Two types of insulin receptors (IRs) have been isolated from S. mansoni (SmIR1 and SmIR2) (Khayath et al. 2007), and S. japonicum (SjIR1 and SjIR2) (You et al. 2010). IR-1 is located on the tegument basal membrane and the internal epithelium of adult worms and plays a role in utilizing host insulin, while SjIR-2 is located in the parenchyma of males and the vitelline tissue of females and has a role in controlling worm growth and development (Khayath et al. 2007; You et al. 2010).

Insulin receptors are suggested as transmission blocking vaccine candidates. Administration of mice with anti-SjIRs antibodies or SjIRs knocking down evoked reduction in glucose uptake, starvation and stunting of adult worms, and reduction in egg output (You et al. 2010, 2015). The development of a vaccine based on the ligand domains of SjIR1 and 2 using peptides derived from their primary sequences, may be feasible due to their low homology to human IR (HIR) and are highly antigenic with the ability to bind human insulin (You et al. 2014). Thus, immunization of CBA mice with the L1 subdomain of the SjIR2 (SjLD2) fusion protein expressed in Escherichia coli resulted in highly significant reductions in numbers of adult worms (40-50\%), mature intestinal eggs (75\%), fecal eggs (56-67\%), and hepatic granuloma density (45-55\%). However, due to the poor immune response generated, it was hard to obtain consistent results using rSjLD2 protein, which had a tendency to degrade during the processes of expression and purification. Nevertheless, further work improving the expression/purification of rSjLD2 is currently underway in order to prevent its degradation (You et al. 2012). Additionally, peptide analogues derived from SjIR1 and SjIR2 have shown high binding affinities to host insulin. These peptide analogues were shown to have more than 10 times higher binding affinity for human insulin than peptides derived from the human IR in the same sequence positions (Stephenson et al. 2016).

\section{Cytosolic vaccines}

\section{Paramyosin}

Paramyosin, a 97-kDa myofibrillar protein with a coiledcoil structure, was exclusively found in invertebrates. It is expressed in the penetration glands of cercariae, the tegument of schistosomula, and the contents of membranebound elongate bodies within the tegument and sub tegmental cell bodies of adult worms. It protects worms from complement-mediated damage by binding human $\mathrm{C} 8$ and $\mathrm{C} 9$ proteins, preventing complement activation at the terminal stage, in vitro and in vivo. Paramyosin protein either native or in a recombinant form was considered a vaccine candidate for protection against schistosomiasis (Gobert and McManus 2005; Deng et al. 2007; McManus and Loukas 2008; Jiz et al. 2015; Eyayu et al. 2020). Additionally, paramyosin peptides were recognized by $\mathrm{T}$ cells of humans resistant to schistosomiasis infection and reinfection (Fonseca et al. 2005; Eyayu et al. 2020).

Due to its location, paramyosin is presumably unavailable for interaction with the immune response (youPearce et al. 1986). Yet, C57BL/6 mice vaccination with native or partial recombinant paramyosin fragment with BCG conferred protection (26-39\%) by stimulating $\mathrm{T}$ cells to produce IFN- $\gamma$ that induces macrophages to kill schistosomula. However, specific epitopes in the immunogen are required because a heterologous paramyosin and myosin from a different invertebrate genus was not protective. These data suggested that paramyosin protective action is cell-mediated and not antibody-dependent (Pearce et al. 1988; McManus and Loukas 2008). On the other hand, mice vaccinated intradermally with $S$. mansoni or schistosomula extracts with Mycobacterium Bovis BCG adjuvant were significantly protected against subsequent infection, and antibodies predominantly recognized paramyosin (Lanar et al. 1986; Sher et al. 1986). In addition, a BALB c/C3H HFl mouse monoclonal IgE antibody recognized S. japonicum paramyosin (Nara et al. 1997), and showed protection (19-58\%) against cercarial infection following passive transfer (Kojima et al. 1987a; b). Conversely, paramyosin immunogen failed to confer the same level of protection in multi-antigen DNA-based form (Tang et al. 2008). Furthermore, immunization of Swiss albino mice three times with purified $\mathrm{Sm} 97$ induced $44.1 \%$, $59.1 \%$, and $61 \%$ reduction in worm burden, intestinal egg loads, and granuloma size, respectively. The protective immunity was associated with high levels of specific antiSm97 IgG1 and IgG2 antibodies (Diab and Aly 2011; Eyayu et al. 2020).

Immunization of C57BL/6 mice with Sm14 peptides alone or mixed with paramyosin peptides reduced worm burden $(26-36.7 \%$ or $28-29.2 \%)$, intestinal eggs $(67 \%$ or 
$46 \%$ ), and also liver pathology (54-61\% or $43-52 \%)$, respectively. Protection was related to a Th1 type immune response provoked by $\mathrm{Sm} 14$ peptide immunization. Thus, vaccination with paramyosin peptide did not mediate protective immunity or reduce pathology and immunization was associated with a Th2 immune response (Garcia et al. 2008).

In contrast, in a large-scale treatment-reinfection study, Th2 cytokine response and $\operatorname{IgE}$ antibody to $\mathrm{Sj} 97$ were shown to be highly associated with resistance to reinfection with S. japonicum (Leenstra et al. 2006; Jiz et al. 2009; Wu et al. 2017). In rodents, its protective potential without adjuvant against $S$. mansoni was $24-53 \%$ and $62-86 \%$ against $S$. japonicum (Jiz et al. 2015; El Ridi and Tallima 2013a). Due to its high immunogenicity against $S$. japonicum, plans are made to move it toward phase I clinical trials.

Thus, the $97 \mathrm{kDa}$ protein is recommended as a promising vaccine candidate for $S$. japonicum (McManus and Loukas 2008; Kurtis et al. 2015; Luna and Campos 2020), principally in sheep, pigs, and water buffaloes. Chinese Sj-97 has shown significant partial protection (32-45\%) in sheep (Taylor et al. 1998), pigs (Chen et al. 2000) and water buffaloes (McManus et al. 2001). Moreover, rSj-97 vaccine formulated with Montanide ISA 206 was strongly immunogenic among water buffaloes resident in an area endemic for schistosomiasis japonicum (Jiz et al. 2016; You et al. 2018). In addition, three independent studies (in 2008, 2013, and 2016) with full-length rSj-97 vaccine formulated with Montanide ISA 206 showed reduction (51.5-60.9\%) in worm burden, and elevated levels of IgG1 and $\mathrm{IgG} 2$ antibodies after challenge infection with S. japonicum (Wu et al. 2017; You et al. 2018).

\section{Gastrointestinal tract vaccine candidates}

One of the most important requirements for S. mansoni survival is the processing of ingested blood in the gut by different peptidases, and nutrients uptake. Impairment of these processes represents an important strategy for vaccine development because the worms will not survive inside the host and will die from starvation. Many digestive tract proteins, which are not recognized by host immune responses during normal infection and are essential for parasite survival, have been tested (Figueiredo et al. 2015).

Schistosoma mansoni lysosome-associated membrane protein (Sm-LAMP) is highly enriched in the digestive tract of $S$. mansoni, located in the gastrodermis. Sm-LAMP in soluble and insoluble form was shown to provide limited protection against $S$. mansoni infection in CBA mice but might be used in combination with other vaccine candidates to provide more protection (Nawaratna et al. 2015).
Another protein possesses a dynein light chain family (DLC/LC8) domain, which is evolutionarily conserved in schistosome and different organisms, and is located in distal gut and in the tegument of schistosomes (Diniz et al. 2014). Recombinant $S$. mansoni DLC12 and DLC13 combined with alhydrogel adjuvant induced high antibody titers (IgG) and decreased worm burden of $43 \%$ and $51 \%$, respectively, and decrease in granuloma size of $70 \%$ in $\mathrm{BALB} / \mathrm{c}$ mice, reflecting the protein Immunoprotection potential (Diniz et al. 2014).

Sm10 protein (also called micro exon gene-4.1) is located on the surface and lumen of the esophageal and intestinal tract of adult worms and lung-stage schistosomula. It was shown to induce a mixed Th1/Th2-type response with reduction in the worm $(25-32 \%)$ and liver egg $(43.6 \%)$ burden as well as a reduction in the number of granulomas (23.8\%) in C57BL/6 mice, suggesting Sm10.3 as a potential vaccine candidate (Martins et al. 2014).

$\mathrm{Sm} 32$ is an asparaginyl peptidase (SmAE) member of the legumain family; it is released as an ESP that hydrolyzes pro-enzymes involved in the degradation of hemoglobin (Dalton and Brindley 1996; Chlichlia et al. 2002). It was shown to induce humoral response against the native protein and $S$. mansoni homogenate when used in DNA formulation but it failed to reduce the challenge worm burden (Chlichlia et al. 2002). Additionally, hydrophilic regions of the molecule with Freund's adjuvant showed limited immunogenicity in rabbits and mice (Noya et al. 2003a; Chacon et al. 2003).

A PDZ (PSD-95/Dlg/ZO-1) domain-containing schistosome protein, syntenin (SmSynt), is localized in the gastrodermis of $S$. mansoni, in spite of none of the proteomic and transcriptional studies identified this protein at this location (Figueiredo et al. 2014). C57BL/6 mice vaccinated with the rSmSynt showed reduction (30-37\%) in worm burden and production of IgG antibodies and Th1-cytokines (Figueiredo et al. 2014).

Four proteins possessing the characteristic saposin domain were identified in schistosome vomit (Hall et al. 2011). A gut saposin-like protein (SmSLP-1) binds sphingolipids, facilitating their degradation by ceramidases and also binds other lipids, sequestering them in the gut lumen for transport and uptake into the cells (Don et al. 2008; Hall et al. 2011). SmSLP-1 has proven to be immunogenic when recombinant form of this protein elicited high antibody titer, but the number of adult worms and eggs recovered from vaccinated $\mathrm{CBA} / \mathrm{CaH}$ mice did not decrease (Don et al. 2008), suggesting that not all gut proteins tested as vaccine were protective.

Indeed, the efficacy of these vaccines remains dependent on the ability of antibodies to bind to these enzymes and inhibit their function. The reason why not all of digestive tract antigens induced protection is because the parasite gut 
$\mathrm{pH}$ is low and seems to be an unsuitable environment for antibodies. Despite that, many digestive tract antigens elicited some protection (Figueiredo et al. 2014).

Additionally, many other antigens like Sm22.6 (Pacifico et al. 2006a; b), ECL or Sm200 (Nascimento et al. 2007; Martins et al. 2012), and Sm21.7 (Ahmed and Romeih 2001; Ahmed et al. 2006) and others also showed ability to provoke significant immune responses, but were not progressed further.

\section{Excretory/secretory proteins}

It was recently documented that actually all $S$. mansoni and $S$. haematobium surface membrane, tegumental and digestive tract candidate vaccine antigens are ESPs, readily detectable in worm derived $15 \mathrm{k}$ (286 proteins) and $120 \mathrm{k}$ (716 proteins) EVs. Sm23, SG3PDH, calpain, Sm-TSP-2, saponin B domain-containing proteins, GST, Sm29, cathepsin domain-containing proteins namely cathepsin B and cathepsin L, proteases, oxidants were identified (Sotillo et al. 2016; Samoil et al. 2018; Kifle et al. 2020a; Mekonnen et al. 2020). El Ridi and Tallima (2009, 2013a) and El Ridi et al. (2015) were the first to advocate that vaccine candidates should only be sought among the developing and migrating larvae ESPs because ESPs are able to induce innate and adaptive immunity and are accessible targets to host immune elements.

Different ESPs molecules have been derived from cercariae, lung-stage schistosomula, and adult worms of several schistosome species (Harrop et al. 1999; Knudsen et al. 2005; Curwen et al. 2006; El Ridi and Tallima 2009; Liao et al. 2011; Young et al. 2012). Most of the schistosome antigens candidates induced type 1 response, except radiation-attenuated cercariae induced Th1-/Th2-immune responses. So, type 1 and 2 immune responses have an essential role in significant parasite elimination and more associated with resistance to reinfection ( $\mathrm{He}$ and Geha 2010; Price et al. 2010; Siracusa et al. 2011; Badr et al. 2015; El Ridi et al. 2015; Tallima et al. 2015).

\section{Recombinant antigens}

Since ESP such as calpain, SG3PDH, 14-3-3-like protein, thioredoxin peroxidase (TPX) etc. in a recombinant form, predominantly elicit poorly protective type 1 immune responses, it was necessary to direct the immune response toward the type $2 \mathrm{arm}$. Cysteine peptidases derived from such diverse sources as papaya (papain; Sokol et al. 2008), house dust mite, Derp1 (Roche et al. 1997; Kikuchi et al. 2006), Leishmania mexicana (Pollock et al. 2003), and many fungal allergens (Shen et al. 1998; Kheradmand et al. 2002) were used (El Ridi and Tallima 2013a). Furthermore, they have the ability to act as adjuvants in the absence of other adjuvants (Chapman et al. 2007; Cunningham et al. 2012). CD-1 mice vaccinated with a combination of the larval ESP, rSG3PDH, and TPX peptide, in conjunction with papain or cytokines, i.e., TSLP (thymic stromal lymphopoietin), IL-25 or IL-33, exhibited predominant Th2 responses, which correlated with highly significant $(P<0.0001)$ reduction of $62-78 \%$ in challenge worm burden (El Ridi and Tallima 2013a).

Since papain, IL-25, IL-33, or TSLP may not be used for human vaccination, they were replaced by a parasitederived cysteine peptidase (El Ridi et al. 2015; Tallima et al. 2015). One of the major worm extract proteins and ESPs is $S$. mansoni cathepsin B1 (SmCB1), a novel critical anti-schistosome vaccine candidate with a capacity to initiate Th17 besides Th1 and Th2 responses (El Ridi et al. 2014a; Ricciardi et al. 2016; Soloviova et al. 2019). SmCB1 and S. mansoni cathepsin L1 (SmCL1, CL) are major hemoglobin-digesting enzymes (Day et al. 1995; Brady et al. 1999a, 1999b, 2000; Bogitsh et al. 2001; Caffrey et al. 2018; Wendt et al. 2020). SmCB1 is expressed at high levels on the caecum and protonephridia of cercariae while SmCL1 is localized to the gastrodermis and the tegument of adult worms (El Ridi et al. 2014b). Both are prominent ESPs, particularly enriched in EVs (Kifle et al. 2020a; b). Recent studies revealed that vinyl sulfone inhibitors of the SmCB1 target will impact the parasite's ability to grow (Jílková et al. 2011, 2020); as well, RNA interference of SmCB1 slowed the growth of the parasite both in culture and in an animal model of infection (Correnti et al. 2005).

Adjuvant-free, enzymatically active SmCB1 or FhCL1 in recombinant form alone or in combination with another vaccine candidate SG3PDH/PRX-MAP were shown to induce high levels of protection with an increase in $\operatorname{IgG} 1$ isotype titers (no IgE was detected), and Th2 cytokines against $S$. mansoni and $S$. haematobium infection, in CD-1 mice and Syrian hamsters, respectively. It was suggested that peptidases can boost early adaptive immune responses, and have in-built immune enhancing properties that are protective on their own, besides having the ability to enhance the protective responses to other molecules (El Ridi et al. 2014a, b; Tallima et al. 2015, 2017a, b). Schistosoma mansoni cathepsin L3 (SmCL3) is another cysteine peptidase that is also expressed in digestive tract of S. mansoni worm (Dvořák et al. 2009). CD-1 mice and Syrian hamsters immunized with enzymatically active rSmCB1 and SmCL3 alone or combined with rSG3PDH induced a significant $(P<0.002)$ protection of (up to 60 and $70 \%$, respectively) against $S$. mansoni and $S$. hematobium challenge infection. This indicated that the efficacious trivalent vaccine should now be used as trials in nonhuman primates for assessment as a potential vaccine to control human schistosomiasis (Tallima et al. 2017a; b). 
Adjuvants were shown to enhance the immunogenicity and protective efficacy of $S$. mansoni cathepsin B (SmCB, $\mathrm{CB}$ ) formulated with $\mathrm{CpG}$ elicited significant protection in C57BL/6 mice characterized by elevated levels of Th1 cytokines (IFN- $\gamma$ and TNF- $\alpha$ ). SmCB formulated with Montanide ISA $720 \mathrm{VG}$ induced significant protection with elevation of both Th1 and Th2 cytokine immune responses (Ricciardi et al. 2015, 2016). A two-dose, starting with oral gavage of attenuated Salmonella enterica Typhimurium strain (YS1646) bearing the nirB_SspH1_CB plasmid followed by intramuscular recombinant enzyme (rCB), or immunization with $\mathrm{rCB}$ combined with sulfated lactosyl archaeol archaeosomes or addavax ${ }^{\mathrm{TM}}$ was able to reduce both worm and tissue egg burdens by $80-90 \%$, which is the best result recorded among $S$. mansoni vaccine candidates in murine model (Hassan et al. 2019; Perera et al. 2020).

Of note, enzymatically inactive SmCB1, Fasciola hepatica cathepsin L1 (FhCL1) (El Ridi et al. 2014a; b), S. haematobium cathepsin L (Abdel Aziz et al. 2019), and papain (Tallima et al. 2019) displayed reduced, yet significant, protective capacity against $S$. mansoni and/or $S$. haematobium challenge infection independently of their proteolytic activity. Furthermore, Tallima and colleagues have found that active and chemically-inactivated non helminth cysteine peptidase, papain induced highly significant reduction ( $>65$ and $40 \%$, respectively) in worm burden associated with $85 \%$ decrease in intestinal egg viability in mice. These results suggested that one or more papain structural motifs might be responsible for induction of the significant protection (Tallima et al. 2019).

All vaccine candidates are now known to be via their transport in EVs available to both elicit immune responses and be accessed by immune effectors, namely antibodies able to hunt and chase the developing schistosomula, forcing their extravasation especially at the lung and liver stage (El Ridi et al. 2017; Sotillo et al. 2016; Samoil et al. 2018; Kifle et al. 2020a; Mekonnen et al. 2020). The reproducible and highly significant reduction in worm burden and worm egg attrition elicited by cysteine peptidases was recently explained. These molecules do not only induce type 2 antibodies, they also result in accumulation of uric acid and arachidonic acid (ARA). It was recently proposed that specific antibodies and the schistosomicide ARA combine towards parasite worm and egg attrition. (Tallima et al. 2019, 2020a; b). Curiously, EV derived from adult $S$. mansoni were found to be internalized by vascular endothelial cells and monocytes and to powerfully up regulate ARA metabolism (Kifle et al. 2020b).

The cysteine peptidase vaccine protection was recently found to be associated with high levels of serum antibodies and an increase in the levels of uric acid and ARA in blood and tissues around 17 days post infection (Tallima et al. 2019, 2020a). Uric acid directed the immune responses towards the type 2 axis, increased the antibody response, and elicited an increase in free ARA, responsible for worm and egg attrition. The powerful oxidant stress-inducing properties of ARA are responsible for its schistosomicidal action, but are counteracted by the anti-oxidant properties of uric acid. It was thus sought to avoid the uric acidinducing capacity of ARA, via use of an enzyme-inactive peptide construct (Tallima et al. 2019, 2020a; b).

\section{Antigenic peptides}

Peptide vaccine might be more useful than whole protein and live-attenuated formulations, because peptide vaccine decreases the possibility of using immunosuppressive epitopes and epitopes that elicit an autoimmune response. However, peptide vaccine presents limitations in terms of obtaining an effective immune response in a population with high genetic variability. The choice of epitopes to form a peptide vaccine depends on their ability to elicit the desirable immune response and to be presented by a wide range of HLA molecules (Purcell et al. 2007). Nevertheless, the efficacy of synthetic peptide vaccine has been evaluated against many microorganisms, and has shown to confer a partial protection in vivo against parasite diseases (Patarroyo et al. 1987; de Oliveira et al. 1994; Noya et al. 2003b). Additionally, synthetic peptides that contain epitopes of infectious agents' protein have been used in the diagnosis of various human diseases (Gómara and Haro 2007).

Regarding schistosomiasis, different vaccine candidates in a peptide construct have been tested. One of those candidates was a peptide containing $\mathrm{B}$ and $\mathrm{T}$ cell epitopes derived from protease inhibitor, kunitz protein of $S$. mansoni, resulted in significant reduction (89-91\%) in female worm burden in BALB/c mice (Hernández-Goenaga et al. 2019). In addition, peptides derived from Sm14, paramyosin, and Sj28GST antigens have shown that Sm14 and Sj28GST induced Th1 immune response against $S$. mansoni and $S$. japonicum infection in C57BL/6 mice (Li et al. 2005; Garcia et al. 2008). Another two peptides derived from SmA263K protein were synthesized as lipid core peptides (LCPs), with or without adjuvant. Antibodies released against LCPs recognized native enzyme in the esophagus and anterior regions of the gastrodermis of adult worms (Dougall et al. 2014).

Actually, most peptides are not immunogenic and they can be easily removed by the body, and hence, must be conjugated to a carrier protein to elicit the required immune responses. The chemical composition of the carrier drawbacks, notably its immune dominancy and low ratio of an antigen to a carrier, limit their use (Tam 1995). Instead peptides were conjugated to protein (bovine serum albumin (BSA), keyhole limpet hemocyanine) or artificial 
carriers (MAPs, sequential oligopeptide carriers, etc.) (Tam 1988; Tsikaris et al. 1996a, b; Mezo et al. 1997).

The MAP formulation allows many peptides to be associated in a single construct, and it can be immunogenic with or without inbuilt adjuvant. It was first developed by Tam (1988), when he replaced the protein carrier with a small score matrix comprising oligomeric lysine, providing a very high density of peptide epitopes at the surface of the construct with a small non-protein core matrix as a scaffold (Fig. 2) (Tam 1988). Synthesizing peptides as MAP and peptide dendrimers can induce higher immune response and recently were used as a vaccine model against Plasmodium falciparum (Mahajan et al. 2010), Yersinia pestis (Shreewastav et al. 2012), filarial nematodes (Immanuel et al. 2017), and human immunodeficiency viruses (HIV) (Sahay et al. 2019). Besides, all required protective B and $\mathrm{T}$ cell epitopes can be included in one single MAP molecule (Fig. 2) (Joshi et al. 2013). Additionally, MAP vaccine systems have been developed to avoid the adverse effects associated with conventional vaccines (i.e., live-attenuated, killed, or inactivated pathogens), carrier proteins, and cytotoxic adjuvants (Fujita and Taguchi 2011).

Schistosoma mansoni SG3PDH mono-epitopic and bisdiepitopic MAP immunogens elicited in C57BL/6 mice considerable cellular and humoral immune responses (Veprek et al. 2004). Thus, six peptides bearing B and $\mathrm{T}$ cell epitopes derived from the primary sequence of $S$. mansoni SG3PDH and synthesized in a dipeptide MAP induced both Th 1 (IgG2a and IgG2b isotypes) and Th2 (IgG1 isotype) immune responses, and elicited the release of IL-2, IL-4, and IFN- $\gamma$ (El Ridi et al. 2004), while the whole molecule containing these peptides could not elicit the release of IL 4 in BALB/c mice and human (El Ridi et al. 1998, 2001a; Tallima et al. 2003). SG3PDH derived MAP construct administered to BALB/c mice appeared to induce both Th1 (IgG2a and IgG2b) and Th2 (IgG1 or IgE) immune responses. This is in line with protective immunity in schistosomiasis requiring both Th1 and Th2 immune responses (Butterworth 1994; Coulson 1997; McManus 1999; Dunne and Mountford 2001; El Ridi 2002; AlSherbiny et al. 2003).

On the other hand, vaccination of C57BL/6 mice with single-epitope-peptide-DNA dual vaccines (PDDV) elicited either $\mathrm{T}$ cytotoxic, $\mathrm{T}$ helper, or $\mathrm{B}$ cell responses. The multicomponents (3 PDDV components) formulation could trigger different immune responses in immunized mice, yet, was less immunoprotective than a single-epitope PDDV formulation. Results suggested that combination of many antigens did not increase the protective potential of the vaccine when compared to the protection of each antigen separately mediated (Wang et al. 2010). However, a bivalent MAP construct containing peptide sequences containing $\mathrm{B}$ and $\mathrm{T}$ cells determinants derived from Sm28GST and SmTPI proteins was shown to induce B-
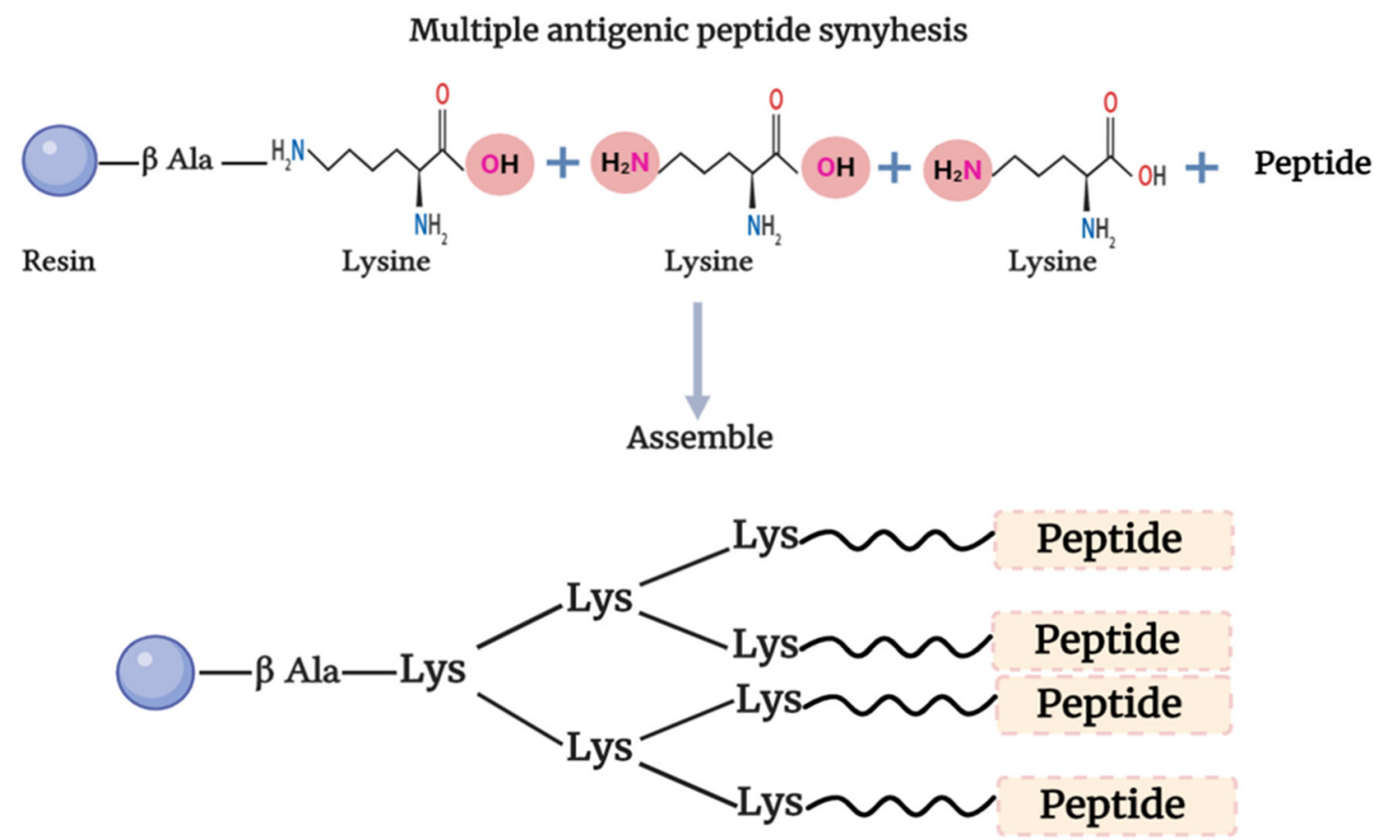

Created in BioRender.com bio

Fig. 2 Multiple antigenic peptide structure 
and T-cell responses and the antibodies were mainly directed not only against the peptide derived from the Sm28GST but also against the whole Sm28GST protein when administered to BALB/c, CBA/N, and C57BL/6 mice (Ferru et al. 1997). MAP construct containing B- and T-cell epitopes derived from SmTPI was used to prime human and murine spleen cells in vitro driving Th1 immune response, and stimulating the release of IFN- $\gamma$ - which play an important role in both $S$. mansoni protective immunity and pathology (La Flamme et al. 2001; Henri et al. 2002; Reis et al. 2008).

Similarly, Sm28GST derived peptides synthesized in two tetravalent mono-epitopic MAPs displayed high antigenicity, indicating that MAPs were stronger agents than monomeric peptides in both specificity and immunogenic activity against schistosome infection in patients and rabbits (Huang et al. 2005).

Otherwise, MAP constructs have elicted significant protection against other parasites, Toxoplasma gondii (Darcy et al. 1992), Fasciola gigantica, (Jezek et al. 2007), Trichinella spiralis (Gu et al. 2020), and microorganisms, Streptococcus mutans OMZ 175 and a mannan from Saccharomyces cerevisiae (Lett et al. 1995).

\section{Concluding remarks}

Schistosomiasis is one of the important helminthic diseases closely linked to poverty and affecting the health. $S$. mansoni infection causes intestinal diseases and affects the liver and spleen. Several countries including Egypt depend on PZQ as chemotherapy against schistosomiasis; however, the appearance of drug resistant strains limits its use. Additionally, mass drug administration alone will not eliminate schistosomiasis. The need for developing vaccine is of great important for public health. Proteins that are specific to schistosomes and show limited similarity with any other proteins are considered as effective and protective vaccine antigens. One of the main clinical endpoints for vaccine efficacy is reduction of schistosomiasis morbidity. Therapeutic potential of vaccine should be tested first in rodents, non-human primates and bovines before using in human clinical trials. Several vaccine candidates have been discovered and showed different protection levels. Protective capacity of vaccines was achieved by induction of either Th1 or Th2 or both responses. Also, protection levels of candidate vaccines are improved after antigen formulation or combining of either different genes or antigens. However, most reseach groups had no financial and logistic abiliy to access trials in baboons or pre-clinincal human trials, resulting in neglect of vaccines that potentially might save millions of lives.
Authors contributions All authors have contributed to the article, wrote, edited and approved its submission, revisions, and submission of the revised version.

Funding None.

Declarations

Conflict of interest No conflict of interest are declared by all authors.

Ethical approval Not Applicable.

\section{References}

Abdel Aziz N, Tallima H, Abou El Dahab M, El Ridi R (2019) Immunogenicity and protective capacity of Schistosoma haematobium recombinant cathepsin $\mathrm{L}$ against infection of hamsters with S. haematobium. Vaccine Res 6:1-8. http://doi.vacres. pasteur.ac.ir/article-1-164-en.pdf

Adekiya TA, Aruleba RT, Klein A, Fadaka AO (2020) In silico inhibition of SGTP4 as a therapeutic target for the treatment of schistosomiasis. J Biomol Struct Dyn. https://doi.org/10.1080/ 07391102.2020.1850363

Affholter JA, Fried VA, Roth RA (1988) Human insulin-degrading enzyme shares structural and functional homologies with Escherichia coli protease III. Science 242:1415-1418. https:// doi.org/10.1126/science.3059494

Ahier A, Khayath N, Vicogne J, Dissous C (2008) Insulin receptors and glucose uptake in the human parasite Schistosoma mansoni. Parasite 15:573-579. https://doi.org/10.1051/parasite/2008 154573

Ahmad G, Torben W, Zhang W, Wyatt M, Siddiqui AA (2009a) Smp80-based DNA vaccine formulation induces potent protective immunity against Schistosoma mansoni. Parasite Immunol 31:156-161. https://doi.org/10.1111/j.1365-3024.2008.01091.x

Ahmad G, Zhang W, Torben W, Damian RT, Wolf RF, White GL, Chavez-Suarez M, Kennedy RC, Siddiqui AA (2009b) Protective and antifecundity effects of Sm-p80-based DNA vaccine formulation against Schistosoma mansoni in a nonhuman primate model. Vaccine 27:2830-2837. https://doi.org/10.1016/ j.vaccine.2009.02.096

Ahmad G, ZhangW TW, Haskins C, Diggs S, Noor Z, Le L, Siddiqui AA (2009c) Prime-boost and recombinant protein vaccination strategies using Sm-p80 protects against Schistosoma mansoni infection in the mouse model to levels previously attainable only by irradiated cercarial vaccine. Parasitol Res 105:1767-1777. https://doi.org/10.1007/s00436-009-1646-z

Ahmed HM, Romeih MH (2001) Protection against Schistosoma mansoni infection with recombinant schistosomula $21.7 \mathrm{kDa}$ protein. Arab J Biotechol 24:229-249

Ahmed HM, Romeih MH, Abou-Shousha TS (2006) DNA immunization with the gene encoding $\mathrm{Sm} 21.7$ protects mice against Schistosoma mansoni infections. Am J Sci 2:59-69

Alsallaq RA, Gurarie D, Ndeffo Mbah M, Galvani A, King C (2017) Quantitative assessment of the impact of partially protective anti-schistosomiasis vaccines. PLoS Negl Trop Dis 11:e0005544. https://doi.org/10.1371/journal.pntd.0005544

Al-Sherbiny M, Osman A, Barakat R, El Morshedy H, Bergquist R, Olds R (2003) In vitro cellular and humoral responses to Schistosoma mansoni vaccine candidate antigens. Acta Trop 88:117-130. https://doi.org/10.1016/s0001-706x(03)00195-5

Alves CC, Araujo N, Bernardes WP, Mendes MM, Oliveira SC, Fonseca CT (2018) A strong humoral immune response induced 
by a vaccine formulation containing $\mathrm{rSm} 29$ adsorbed to alum is associated with protection against Schistosoma mansoni reinfection in mice. Front Immunol 9:2488. https://doi.org/10.3389/ fimmu.2018.02488

Alves CC, Araujo N, dos Santos VCF, Couto FB, Assis NR, Morais SB, Oliveira SC, Fonseca CT (2015) Sm29, but not Sm22,6 retains its ability to induce a protective immune response in mice previously exposed to a Schistosoma mansoni infection. PLOS Negl Trop Dis 9:e0003537. https://doi.org/10.1371/journal. pntd.0003537

Assis NR, Caires AJ, Figueiredo BC, Morais SB, Mambelli FS, Marinho FV, Ladeira LO, Oliveira SC (2018) The use of gold nanorods as a new vaccine platform against schistosomiasis. J Control Release 275:40-52. https://doi.org/10.1016/j.jconrel. 2018.02.004

Badr AM, Al-Halbosiy M, El Ridi R (2015) Differential immune responses to excretory-secretory antigens of lung-stage larvae of Schistosoma mansoni in mice and rats. J Basic Appl Zool 69:26-33

Baiocco P, Gourlay LJ, Angelucci F, Fontaine J, Herve M, Miele AE, Trottein F, Brunori M, Bellelli A (2006) Probing the mechanism of GSH activation in Schistosoma haematobium glutathione-S transferase by site-directed mutagenesis and X-ray crystallography. J Mol Biol 360:678-689. https://doi.org/10.1016/j. jmb.2006.05.040

Balloul JM, Pierce RJ, Grzych JM, Capron A (1985) In vitro synthesis of a 28 kilodalton antigen present on the surface of the schistosomulum of Schistosoma mansoni. Mol Biochem Parasitol 17:105-114. https://doi.org/10.1016/0166-6851(85)90131-8

Bear JW, Long T, Skinner D, McKerrow JH (2018) Predictions of novel Schistosoma mansoni- human protein interactions consistent with experimental data. Sci Rep 8:1-14. https://doi.org/ 10.1038/s41598-018-31272-1

Bogitsh BJ, Dalton JP, Brady CP, Brindley PJ (2001) Gut-associated immunolocalization of the Schistosoma mansoni cysteine proteases, SmCL1 and SmCL2. J Parasitol 87:237-241. https://doi.org/10.1645/00223395(2001)087[0237:GAIOTS]2.0.CO;2

Boulanger D, Reid GD, Sturrock RF, Wolowczuk I, Balloul JM, Grezel D, Pierce RJ, Otieno MF, Guerret S, Grimaud A, Butterworth AE, Capron A (1991) Immunization of mice and baboons with the recombinant Sm28GST affects both worm viability and fecundity after experimental infection with Schistsoma mansoni. Parasite Immunol 13:473-490. https://doi.org/ 10.1111/j.1365-3024.1991.tb00545.x

Boulanger D, Warter A, Trottein F, Mauny F, Brémond P, Audibert F, Couret D, Kadri S, Godin C, Sellin E, Pierce RJ, Lecoco JP, Sellin B, Capron A (1995) Vaccination of patas monkeys experimentally infected with Schistosoma haematobium using a recombinant glutathione S-transferase cloned from $S$. mansoni. Parasite Immunol 17:361-369. https://doi.org/10.1111/j.13653024.1995.tb00903.x

Boulanger D, Warter A, Sellin B, Lindner V, Pierce RJ, Chippaux JP, Capron A (1999) Vaccine potential of a recombinant glutathione S-transferase cloned from Schistosoma haematobium in primates experimentally infected with a homologous challenge. Vaccine 17:319-326. https://doi.org/10.1016/s0264-410x(98)00202-3

Brady CP, Brindley PJ, Dowd AJ, Dalton JP (2000) Schistosoma mansoni: differential expression of cathepsins L1 and L2 suggests discrete biological functions for each enzyme. Exp Parasitol 94:75-83. https://doi.org/10.1006/expr.1999.4478

Brady CP, Dowd AJ, Brindley PJ, Ryan T, Day S, Dalton JP (1999a) Recombinant expression and localization of Schistosoma mansoni cathepsin L1 support its role in the degradation of host hemoglobin. Infect Immun 67:368-374. https://doi.org/ 10.1128/IAI.67.1.368-374.1999
Brady CP, Dowd AJ, Tort J, Roche L, Condon B, O'Neill SM, Brindley PJ, Dalton JP (1999b) the cathepsin L-like proteinases of liver fluke and blood fluke parasites of the trematode genera Fasciola and Schistosoma. Biochem Soc Trans 27:740-745. https://doi.org/10.1042/bst0270740

Braschi S, Curwen RS, Ashton PD, Verjovski-Almeida S, Wilson A (2006) The tegument surface membranes of the human blood parasite Schistosoma mansoni: a proteomic analysis after differential extraction. Proteomics 6:1471-1482. https://doi.org/ 10.1002/pmic.200500368

Braschi S, Wilson RA (2006) Proteins exposed at the adult schistosome surface revealed by biotinylation. Mol Cell Proteom 5:347-356. https://doi.org/10.1074/mcp.M500287-MCP200

Brito CF, Oliveira GC, Oliveira SC, Street M, Riengrojpitak S, Wilson RA, Simpson AJ, Correa-Oliveira R (2002) Sm14 gene expression in different stages of the Schistosoma mansoni life cycle and immunolocalization of the Sm14 protein within the adult worm. Braz J Med Biol Res 35:377-381. https://doi.org/ 10.1590/s0100-879x2002000300014

Bushara HO, Bashir ME, Malik KH, Mukhtar MM, Trottein F, Capron A, Taylor MG (1993) Suppression of Schistosoma bovisegg production in cattle by vaccination with either glutathione stransferase or keyhole limpet haemocyanin. Parasite Immunol 15:383-390. https://doi.org/10.1111/j.1365-3024. 1993.tb00623.x

Butterworth AE (1994) Human immunity to schistosomes: some questions. Parasitol Today 10:378-380. https://doi.org/10.1016/ 0169-4758(94)90225-9

Caffrey CR, Goupil L, Rebello KM, Dalton JP, Smith D (2018) Cysteine proteases as digestive enzymes in parasitic helminths. PLoS Neg Trop Dis 12:e0005840. https://doi.org/10.1371/ journal.pntd.0005840

Capron A, Riveau G, Grzych JM, Boulanger D, Capron M, Pierce RJ (1994) Development of a vaccine strategy against human and bovine schistosomiasis background and update. Trop Geogr Med 46:242-246

Capron A, Riveau G, Capron M, Trottein F (2005) Schistosomes: the road from host-parasite interactions to vaccines in clinical trials. Trends Parasitol 21:143-149. https://doi.org/10.1016/j. pt.2005.01.003

Cardoso FC, Macedo GC, Gava E, Kitten GT, Mati VM, de Melo AL, Caliari MV, Almeida GT, Venancio TM, Almeida SV, Oliveira SC (2008) Schistosoma mansoni tegument protein Sm29 is able to induce a Th1-type of immune response and protection against parasite infection. PloS Negl Trop Dis 2:e308. https:// doi.org/10.1371/journal.pntd.0000308

Cardoso FC, Pacifico RN, Mortara RA, Oliveira SC (2006a) Human antibody responses of patients living in endemic areas for schistosomiasis to the tegumental protein Sm29 identified through genomic studies. Clin Exp Immunol 144:382-391. https://doi.org/10.1111/j.1365-2249.2006.03081.x

Cardoso FC, Pinho JMR, Azevedo V, Oliveira SC (2006b) Identification of a new Schistosoma mansoni membrane bound protein through bioinformatic analysis. Genet Mol Res 5:609-618

Carvalho-Queiroz C, Nyakundi R, Ogongo P, Rikoi H, Egilmez NK, Farah IO, Kariuki TM, Loverde PT (2015) Protective potential of antioxidant enzymes as vaccines for schistosomiasis in a nonhuman primate model. Front Immunol 6:273. https:// doi.org/10.3389/fimmu.2015.00273

Castro-Borges W, Dowle A, Curwen RS, Thomas-Oates J, Wilson RA (2011) Enzymatic shaving of the tegument surface of live schistosomes for proteomic analysis: a rational approach to select vaccine candidates. PLoS Negl Trop Dis 5:e993. https:// doi.org/10.1371/journal.pntd.0000993

Chacon N, LosadaS BH, Cesari IM, Hoebeke J, Noya O (2003) Immunogenicity of polymerizable synthetic peptides derived 
from a vaccine candidate against schistosomiasis: the asparaginyl endopeptidase (Sm32). Immunol Lett 88:199-210. https:// doi.org/10.1016/s0165-2478(03)00084-1

Chapman MD, Wünschmann S, Pomés A (2007) Proteases as Th2 adjuvants. Curr Allerg Asthma Rep 7:363-367. https://doi.org/ 10.1007/s11882-016-0622-9

Chen H, Nara T, Zeng X, Satoh M, Wu G, Jiang W, Yi F, Kojima S, Zhang S, Hirayama K (2000) Vaccination of domestic pig with recombinant paramyosin against Schistosoma japonicum in China. Vaccine 18:2142-2146. https://doi.org/10.1016/s0264410x(99)00541-1

Chisha Y, Zerdo Z, Asnakew M, Churko C, Yihune M, Teshome A, Nigussu N, Seife F, Getachew B, Sileshi M (2020) Praziquantel treatment coverage among school age children against Schistosomiasis and associated factors in Ethiopia: a cross-sectional survey, 2019. BMC Infect Dis 20(1):872. https://doi.org/ 10.1186/s12879-020-05519-0

Chiumiento L, Bruschi F (2009) Enzymatic antioxidant systems in helminth parasites. Parasitol Res 105:593-603. https://doi.org/ 10.1007/s00436-009-1483-0

Chlichlia K, Bahgat M, Ruppel A, Schirrmacher V (2002) DNA vaccination with asparaginyl endopeptidase ( $\mathrm{Sm} 32)$ from the parasite Schistsoma mansoni: antifecundity effect induced in mice. Vaccine 20:439-447. https://doi.org/10.1016/s0264410x(01)00345-0

Cook RM, Carvalho-Queiroz C, Wilding G, LoVerde PT (2004) Nucleic acid vaccination with Schistosoma mansoni antioxidant enzyme cytosolic superoxide dismutase and the structural protein filamin confers protection against the adult worm stage. Infect Immun 72:6112-6124. https://doi.org/10.1128/IAI.72.10.61126124.2004

Correa-Oliveira R, Caldas IR, Gazzinelli G (2000) Natural versus drug-induced resistance in Schistosoma mansoni infection. Parasitol 16:397-399. https://doi.org/10.1016/j.micinf.2007. 08.004

Correa-Oliveira R, Pearce EJ, Oliveira GC, Golgher DB, Katz N, Bahia LG, Carvalho OS, Gazzinelli G, Sher A (1989) The human immune response to defined immunogens of Schistosoma mansoni: elevated antibody levels to paramyosin in stoolnegative individuals from two endemic areas in Brazil. Trans R Soc Trop Med Hyg 83:798-804. https://doi.org/10.1016/ 0035-9203(89)90334-9

Correnti JM, Brindley PJ, Pearce EJ (2005) Long-term suppression of cathepsin B levels by RNA interference retards schistosome growth. Mol Biochem Parasitol 143:209-215. https://doi.org/ 10.1016/j.molbiopara.2005.06.007

Coulson PS (1997) The radiation-attenuated vaccine against schistosomes in animal models: paradigm for a human vaccine? Adv Parasitol 39:271-336. https://doi.org/10.1016/s0065-308x (08)60048-2

Coulson PS, Wilson RA (1997) Recruitment of lymphocytes to the lung through vaccination enhances the immunity of mice exposed to irradiated schistosomes. Infect Immun 65:42-48. https://doi.org/10.1128/IAI.65.1.42-48.1997

Cunningham PT, Ellio CE, Lenzo JC, Jarnicki AG, Larcombe AN, Zosky GR, Holt PG, Thomas WR (2012) Sensitizing and Th2 adjuvant activity of cysteine protease allergens. Int Arch Allerg Immunol 158:347-358. https://doi.org/10.1159/000334280

Curwen RS, Ashton PD, Sundaralingam S, Wilson RA (2006) Identification of novel proteases and immunomodulators in the secretions of schistosome cercariae that facilitate host entry. Mol Cell Proteom 5:835-844. https://doi.org/10.1074/mcp. M500313-MCP200

Da'dara AA, Skelly PJ, Walker CM, Harn DA (2003) DNA prime/ protein boost A DNA-prime/protein-boost vaccination regimen enhances Th2 immune responses but not protection following
Schistosoma mansoni infection. Parasite Immunol 25:429-437. https://doi.org/10.1111/j.1365-3024.2003.00651.x

Da'dara AA, Skelly PJ, Wang MM, Harn DA (2001) Immunization with plasmid DNA encoding the integral membrane protein, Sm23, elicits a protective immune response against schistosome infection in mice. Vaccine 20:359-369. https://doi.org/10. 1016/s0264-410x(01)00374-7

Dalton JP, Brindley PJ (1996) Schistosome asparaginyl endopeptidase Sm32 in hemoglobin digestion. Parasitol Today 12:125-129. https://doi.org/10.1016/0169-4758(96)80676-4

Darcy F, Maes P, Gras-Masse H, Auriault C, Bossus M, Deslee D, Godard I, Cesbron MF, Tartar A, Capron A (1992) Protection of mice and nude rats against toxoplasmosis by a multiple antigenic peptide construction derived from Toxoplasma gondii P30 antigen. J Immunol 149:3636-3641

Day SR, Dalton JP, Clough KA, Leonardo L, Tiu WU, Brindley PJ (1995) Characterization and cloning of the cathepsin L proteinases of Schistosoma japonicum. Biochem Biophys Res Commun 217:1-9. https://doi.org/10.1006/bbrc.1995.2737

Deng J, Gold D, LoVerde PT, Fishelson Z (2007) Mapping of the complement $\mathrm{C} 9$ binding domain in paramyosin of the blood fluke Schistosoma mansoni. Int J Parasitol 37:67-75. https://doi.org/10.1016/j.ijpara.2006.09.011

Deol AK, Fleming FM, Calvo-Urbano B, Walker M, Bucumi V, Gnandou I, Tukahebwa EM, Jemu S, Mwingira UJ, Alkohlani A, Traoré M, Ruberanziza E, Touré S, Basáñez MG, French MD, Webster JP (2019) Schistosomiasis-assessing pogress toward the 2020 and 2025 global goals. N Engl J Med 26(381):2519-2528. https://doi.org/10.1056/NEJMoa1812165

De Oliveira G, Clavijo P, Nussenzweig RS, Nardin EH (1994) Immunogenicity of an alum-adsorbed synthetic multiple-antigen peptide based on B- and T-cell epitopes of the Plasmodium falciparumCS protein: possible vaccine application. Vaccine 12:1012-1017. https://doi.org/10.1016/0264-410x(94)90337-9

Diab T, Aly I (2011) Efficacy of Schistosoma mansoni paramyosin (Sm97) and fatty acid binding protein (Sm-FABP) as a candidate vaccine against schistosomiasis mansoni. Int J Infect Dis 15:S97

Di Bella S, Riccardi N, Giacobbe DR, Luzzati R (2018) History of schistosomiasis (bilharziasis) in humans: from Egyptian medical papyri to molecular biology on mummies. Pathog Glob Health 112:268-273. https://doi.org/10.1080/20477724.2018.1495357

Diniz PP, Nakajima E, Miyasato PA, Nakano E, de Oliveira RM, Martins EA (2014) Two SmDLC antigens as potential vaccines against schistosomiasis. Acta Trop 140:193-201. https://doi. org/10.1016/j.actatropica.2014.09.006

Don TA, Bethony JM, Loukas A (2008) Saposin-like proteins are expressed in the gastrodermis of Schistosoma mansoni and are immunogenic in natural infections. Int J Infect Dis 12:39-47. https://doi.org/10.1016/j.ijid.2007.10.007

Dougall AM, Skwarczynski M, Khoshnejad M, Chandrudu S, Daly NL, Toth I, Loukas A (2014) Lipid core peptide targeting the cathepsin D hemoglobinase of Schistosoma mansonias a component of a schistosomiasis vaccine. Hum Vaccine Immunother 10:399-409. https://doi.org/10.4161/hv.27057

Dunne D, Mountford A (2001) Resistance to infection in humans and animal models. In: Mahmoud AAF (ed) Schistosomiasis. Imperial College Press, pp 133-212

Dvorák J, Mashiyama ST, Sajid M, Braschi S, Delcroix M, Schneider EL, McKerrow WH, Bahgat M, Hansell E, Babbitt PC, Craik CS (2009) SmCL3, a gastrodermal cysteine protease of the human blood fluke Schistosoma mansoni. PloS Negl Trop Dis 3:e449. https://doi.org/10.1371/journal.pntd.0000449

El Ridi R (2002) Toward a complete immunity-inducing vaccine for schistosomiasis. J Parasitol 88:1049-1050. https://doi.org/ 10.1645/0022-3395(2002)088[1049:TACIIV]2.0.CO;2 
El Ridi R, Tallima H (2006) Equilibrium in lung schistosomula sphingomyelin breakdown and biosynthesis allows very small molecules, but not antibody, to access proteins at the host parasite interface. J Parasitol 92:730-737. https://doi.org/10. 1645/GE-745R1.1

El Ridi R, Tallima H (2009) Schistosoma mansoni ex vivo lung-stage larvae excretory-secretory antigens as vaccine candidates against schistosomiasis. Vaccine 27:666-673. https://doi.org/ 10.1016/j.vaccine.2008.11.039

El Ridi R, Farouk F, Sherif M, Osman A, El Gengehi N, Shoemaker $\mathrm{CB}$ (1998) $\mathrm{T}$ and $\mathrm{B}$ cell reactivity to a $42-\mathrm{kDa}$ protein is associated with human resistance to both Schistosoma mansoniandhaematobium. J Infect Dis 177:1364-1372. https://doi.org/10.1086/515274

El Ridi R, Mahrous A, Afifi A, Montash M, Velek J, Jezek J (2001a) Human and murine humoral immune recognition of multiple peptides from Schistosoma mansoni glyceraldehyde 3-P dehydrogenase is associated with resistance to Schistosomiasis. Scand J Immunol 54:477-485. https://doi.org/10.1046/j.1365 $-3083.2001 .00992 . \mathrm{x}$

El Ridi R, Shoemaker CB, Farouk F, El Sherif NH, Afifi A (2001b) Human $\mathrm{T}$ - and B-cell responses to Schistosoma mansoni recombinant glyceraldehyde 3-phosphate dehydrogenase correlate with resistance to reinfection with Schistosoma mansoni or Schistosoma haematobium after chemotherapy. Infect Immun 69:237-244. https://doi.org/10.1128/IAI.69.1.237-244.2001

El Ridi R, Montash M, Tallima H (2004) Immunogenicity and vaccine potential of dipeptidic multiple antigen peptides from schistosoma mansoniglyceraldehyde 3-phosphate dehydrogenase. Scand J Immunol 60:392-402. https://doi.org/10.1111 /j.0300-9475.2004.01497.x

El Ridi R, Tallima H (2013a) Vaccine-induced protection against murine schistosoma mansoni with larval excretory-secretory antigens and papain or type-2 cytokines. J Parasitol 99:194-202. https://doi.org/10.1645/GE-3186.1

El Ridi R, Tallima H (2013b) Novel therapeutic and prevention ppproaches for schistosomiasis: review. J Adv Res 4:467-478. https://doi.org/10.1016/j.jare.2012.05.002

El Ridi R, Tallima H, Dalton JP, Donnelly S (2014b) Induction of protective immune responses against schistosomiasis using functionally active cysteine peptidases. Front Genet 5:119. https://doi.org/10.3389/fgene.2014.00119

El Ridi R, Tallima H, Selim S, Donnelly S, Cotton S, Gonzales Santana B, Dalton JP (2014a) Cysteine peptidases as schistosomiasis vaccines with inbuilt adjuvanticity. PLoS ONE 9:e85401. https://doi.org/10.1371/journal.pone.0085401

El Ridi R, Othman AA, McManus DP (2015) Editorial: the schistosomiasis vaccine-it is time to stand up. Front Immunol 6:390. https://doi.org/10.3389/fimmu.2015.00390

El Ridi R, Tallima H, Migliardo F (2017) Biochemical and quasielastic neutron scattering methodologies open the road for effective schistosomiasis therapy and vaccination. Biochim Biophys Acta Gen Subj 1861:3613-3620. https://doi.org/10. 1016/j.bbagen.2016.03.036

Eyayu T, Zeleke AJ, Worku L (2020) Current status and future prospects of protein vaccine candidates against Schistosoma mansoni infection. Parasite Epidemiol Control 11:e00176. https://doi.org/10.1016/j.parepi.2020.e00176

Ferru I, Georges B, Bossus M, Estaquier J, Delacre M, Harns DA, Tartar A, Capron A, Grassmasse H, Auriault C (1997) Analysis of the immune response elicited by a multiple antigen peptide (MAP) composed of two distinct protective antigens derived from the parasite Schistosoma mansoni. Parasite Immuno 19:1-11. https://doi.org/10.1046/j.1365-3024.1997.d01-138.x

Figueiredo BC, de Assis NR, Morais SB, Ricci ND, Pinheiro CS, Martins VP, Bicalho RM, Da'dara AA, Skelly PJ, Oliveira SC
(2014) Schistosome syntenin partially protects vaccinated mice against Schistosoma mansoni infection. PloS Negl Trop Dis 8:e3107. https://doi.org/10.3389/fimmu.2015.00022

Figueiredo BC, Ricci ND, de Assis NR, de Morais SB, Fonseca CT, Oliveira SC (2015) Kicking in the guts: Schistosoma mansoni digestive tract proteins are potential candidates for vaccine development. Front Immunol 6:22. https://doi.org/10. 3389/fimmu.2015.00022

Fonseca CT, Braz Figueiredo Carvalho G, Carvalho Alves C, de Melo TT (2012) Schistosoma tegument proteins in vaccine and diagnosis development: an update. J Parasitol Res 2012:541268. https://doi.org/10.1155/2012/541268

Fonseca CT, Cunha-Neto E, Goldberg AC, Kalil J, de Jesus AR, Carvalho EM, Correa-Oliveira R, Hammer J, Sidney J, Sette A, Oliveira SC (2005) Identification of paramyosin T cell epitopes associated with human resistance to Schistosoma mansonireinfection. Clin Exp Immunol 142:539-547

Fujita Y, Taguchi H (2011) Current status of multiple antigenpresenting peptide vaccine systems: application of organic and inorganic nanoparticles. Chem Cent $\mathrm{J}$ 5:48. https://doi .org/10.1186/1752-153X-5-48

Ganley-Leal LM, Guarner J, Todd CW, Da'Dara AA, Freeman GL Jr, Boyer AE, Harn DA, Secor WE (2005) Comparison of Schistosoma mansoni irradiated cercariae and Sm23 DNA vaccines. Parasite Immunol. https://doi.org/10.1111/j.13653024.2005.00785.x

Garcia TC, Fonseca CT, Pacifico LG, Durães Fdo V, Marinho FA, Penido ML, Caliari MV, de Melo AL, Pinto HA, Barsante MM, Cunha-Neto E, Oliveira SC (2008) Peptides containing T cell epitopes, derived from Sm14, but not from paramyosin, induce a Th1 type of immune response, reduction in liver pathology and partial protection against Schistosoma mansoniinfection in mice. Acta Trop 106:162-167. https://doi.org/10.1016/j.actatropica .2008 .03 .003

Gobert GN, McManus DP (2005) Update on paramyosin in parasitic worms. Parasitol Int 54:101-107. https://doi.org/10. 1016/j.parint.2005.02.004

Gómara MJ, Haro I (2007) Synthetic peptides for the immunodiagnosis of human diseases. Curr Med Chem 14:531-546. https://doi.org/10.2174/092986707780059698

Goudot-Crozel V, Caillol D, Djabali M, Dessein AJ (1989) The major parasite surface antigen associated with human resistance to schistosomiasis is a $37-\mathrm{kD}$ glyceraldehyde-3Pdehydrogenase. J Exp Med 170:2065-2080. https://doi.org/10.1084/jem.170. 6.2065

Gu Y, Sun X, Huang J, Zhan B, Zhu X (2020) A multiple antigen peptide vaccine containing $\mathrm{CD} 4+\mathrm{t}$ cell epitopes enhances humoral immunity against Trichinella spiralis infection in mice. J Immunol Res 8:2074803. https://doi.org/10.1155/ 2020/2074803

Hall SL, Braschi S, Truscott M, Mathieson W, Cesari I, Wilson RA (2011) Insights in to blood feeding by schistosomes from a proteomic analysis of worm vomitus. Mol Biochem Parasitol 179:18-29. https://doi.org/10.1016/j.molbiopara.2011.05.002

Hansell E, Braschi S, Medzihradszky KF, Sajid M, Debnath M, Ingram J, Lim KC, Mckerrow JH (2008) Proteomic analysis of skin invasion by blood fluke larvae. PLoS Negl Trop Dis 2:e262. https://doi.org/10.1371/journal.pntd.0000262

Harn DA, Mitsuyama M, Huguenel ED, David JR (1985) Schistosoma mansoni: detection by monoclonal antibody of a $22,000-\mathrm{Da}$ surface membrane antigen which may be blocked by host molecules on lung stage parasites. J Immunol 135:2115-2120

Harn DA, Reynolds SR, Chikunguwo S, Furlong S, Dahl C (1995) Synthetic peptide vaccines for schistosomiasis. Pharm Biotechnol 6:891-905. https://doi.org/10.1007/978-1-4615-1823-5_40 
Harrop R, Coulson PS, Wilson RA (1999) Characterization, cloning and immunogenicity of antigens released by lung-stage larvae of Schistosoma mansoni. Parasitology 118:583-594. https://doi.org/10.1017/s003118209900431x

Hassan AS, Zelt NH, Perera DJ, Ndao M, Ward BJ (2019) Vaccination against the digestive enzyme Cathepsin B using a YS1646 Salmonella enterica Typhimurium vector provides almost complete protection against Schistosoma mansoni challenge in a mouse model. PloS Negl Trop Dis 13:e007490. https://doi.org/10.1371/journal.pntd.0007490

He R, Geha RS (2010) Thymic stromal lymphopoietin. Ann NY Acad Sci 1183:13-24. https://doi.org/10.1111/j.1749-6632.2009 .05128.x

Henri S, Chevillard C, Mergani A, Paris P, Gaudart J, Camilla C, Dessein H, Montero F, Elwali NE, Saeed OK, Magzoub M, Dessein AJ (2002) Cytokine regulation of periportal fibrosis in humans infected with Schistosoma mansoni: IFN gamma is associated with protection against fibrosis and TNF-alpha with aggravation of disease. J Immunol 169:929-936. https://doi. org/10.4049/jimmunol.169.2.929

Hernández-Goenaga J, López-Abán J, Protasio AV, Vicente Santiago B, Del Olmo E, Vanegas M, Fernández-Soto P, Patarroyo MA, Muro A (2019) Peptides derived of kunitz-type serine protease inhibitor as potential vaccine against experimental schistosomiasis. Front Immunol 10:2498. https://doi.org/10.3389 /fimmu.2019.02498

Hewitson JP, Maizels RM (2014) Vaccination against helminthes parasite infections. Expert Rev Vaccines 13:473-487. https://doi.org/10.1586/14760584.2014.893195

Hong Z, Kosman DJ, Thakur A, Rekosh D, LoVerde PT (1992) Identification and purification of a second form of $\mathrm{Cu} / \mathrm{Zn}$ superoxide dismutase from Schistosoma mansoni. Infect Immun 60:3641-3651. https://doi.org/10.1128/IAI.60.9.3641-3651.1992

Hotez PJ, Bottazzi ME, Bethony J, Diemert DD (2019) Advancing the development of a human schistosomiasis vaccine. Trends Parasitol 35:104-108. https://doi.org/10.1016/j.pt.2018.10.005

Huang HQ, Li SC, Qin ZH, Cao SL, Yao Y, Liu YS, Shi YE (2005) Synthesis and bioactivities of two multiple antigen peptides as potential vaccine against schistosoma. Bioorg Med Chem Lett 15:2415-2419. https://doi.org/10.1016/j.bmcl.2005.01.040

Huberts DH, van der Klei IJ (2010) Moonlighting proteins: an intriguing mode of multitasking. Biochim Biophys Acta 1803:520-525. https://doi.org/10.1016/j.bbamcr.2010.01.022

Immanuel C, Ramanathan A, Balasubramaniyan M, Khatr VK, Amdare NP, Rao DN, Reddy MVR, Perumal K (2017) Immune prophylaxis of multi-antigen peptide (MAP) vaccine for human lymphatic filariasis. Immunol Res 65:729-738. https://doi.org/10.1007/s12026-017-8911-5

Jezek J, El Ridi R, Salah M, Wagih A, Aziz HW, Tallima H, El Shafie MH, Abdel Khalek T, Abo Ammou F, Strongylis C, Moussis V, Tsikaris V (2007) Fasciola gigantica cathepsin L proteinasebased synthetic peptide for immunodiagnosis and prevention of sheep fasciolosis. Biopolymers 90:349-357. https://doi.org/10. 1002/bip.20788

Jílková A, Rubešová P, Fanfrlík J, Fajtová P, Řezáčová P, Brynda J, Lepšík M, Mertlíková-Kaiserová H, Emal CD, Renslo AR, Roush WR, Horn M, Caffrey CR, Mareš M (2020) Druggable hot spots in the schistosomiasis cathepsin $\mathrm{b} 1$ target identified by functional and binding mode analysis of potent vinyl sulfone inhibitors. ACS Infect Dis. https://doi.org/10.1021/acsin fecdis.0c00501

Jílková A, Rezácová P, Lepsík M, Horn M, Váchová J, Fanfrlík J, Brynda J, McKerrow JH, Caffrey CR, Mares M (2011) Structural basis for inhibition of cathepsin B drug target from the human blood fluke, Schistosoma mansoni. J Biol Chem 286:35770-35781. https://doi.org/10.1074/jbc.M111.271304
Jiz M, Friedman JF, Leenstra T, Jarilla B, Pablo A, Langdon G, PondTor S, Wu HW, Manalo D, Olveda R, Acosta L, Kurtis JD (2009) Immunoglobulin E (IgE) responses to paramyosin predict resistance to reinfection with Schistosoma japonicum and are attenuated by IgG4. Infect Immun 77:2051-2058. https://doi.org/10.1128/IAI.00012-09

Jiz MA, Mingala CN, Lopez IFM, Chua M, Gabonada FG Jr, Acosta LP, Wu H, Kurtis JD (2016) A field trial of recombinant Schistosoma japonicum paramyosin as a potential vaccine in naturally-infected water buffaloes. Ann Parasitol 62:295-299. https://doi.org/10.17420/ap6204.64

Jiz MA, Wu H, Olveda R, Jarilla B, Kurtis JD (2015) Development of paramyosin as a vaccine candidate for schistosomiasis. Front Immunol 6:347. https://doi.org/10.3389/fimmu.2015.00347

Johnson KA, Angelucci F, Bellelli A, Herve M, Fontaine J, Tsernoglou D, Capron A, Trottein F, Brunori M (2003) Crystal structure of the $28 \mathrm{kDa}$ glutathione-S-transferase from Schistosoma haematobium. Biochemistry 42:10084-10094. https://doi.org/10.1021/bi034449r

Joshi VG, Dighe VD, Thakuria D, Malik YS, Kumar S (2013) Multiple antigenic peptide (MAP): a synthetic peptide dendrimer for diagnostic, antiviral and vaccine strategies for emerging and re-emerging viral diseases. Indian J Virol 24:312-320. https://doi.org/10.1007/s13337-013-0162-z

Karmakar S, Zhang W, Ahmad G, Torben W, Alam MU, Le L, Damian RT, Wolf RF, White GL, Carey DW, Carter C, Reed SG, Siddiqui AA (2014a) Use of a Smp80-based therapeutic vaccine to kill established adult schistosome parasites in chronically infected baboons. J Infect Dis 209:1929-1940. https://doi.org/10.1093/infdis/jiu031

Karmakar S, Zhang W, Ahmad G, Alam MU, Winn R, Torben W, Le L, Tillery KA, Siddiqui AA (2014b) Complement plays a minimal role in Sm-p80-mediated protection against Schistosoma mansoni. Hum Vaccine Immunother 10:640-647. https://doi.org/10.4161/hv.27576

Karmakar S, Zhang W, Ahmad G, Torben W, Alam MU, Le L, Damian RT, Wolf RF, White GL, Carey DW, Carter C, Reed SG, Siddiqui AA (2014c) Cross-species protection: Schistosoma mansoni $\mathrm{Sm}$-p80 vaccine confers protection againstSchistosoma haematobium in hamsters and baboons. Vaccine 32:1296-1303. https://doi.org/10.1016/j.vaccine.2013.12.057

Keating JH, Wilson RA, Skelly PJ (2006) No overt cellular inflammation around intravascular schistosomes in vivo. J Parasitol 92:1365-1369. https://doi.org/10.1645/GE-864R.1

Keitel WA, Potter GE, Diemert D, Bethony J, El Sahly HM, Kennedy JK, Patel SM, Plieskatt JL, Jones W, Deye G, Bottazzi ME, Hotez PJ, Atmar RL (2019) A phase 1 study of the safety, reactogenicity, and immunogenicity of a Schistosoma mansoni vaccine with or without glucopyranosyl lipid an aqueous formulation (GLA-AF) in healthy adults from a non-endemic area. Vaccine 37:6500-6509. https://doi.org/10.1016 /j.vaccine.2019.08.075

Khayath N, Vicogne J, Ahier A, Benyounes A, Konrad C, Trolet J, Viscogliosi E, Brehm K, Dissous C (2007) Diversification of the insulin receptor family in the helminth parasite Schistosoma mansoni. FEBS J 274:659-676. https://doi.org/10. 1111/j.1742-4658.2006.05610.x

Kheradmand F, Kiss A, Xu J, Lee SH, Kolattukudy PE, Corry DB (2002) A protease activated pathway underlying Th cell type 2 activation and allergic lung disease. J Immunol 169:5904-5911. https://doi.org/10.4049/jimmunol.169.10.5904

Kifle DW, Pearson MS, Becker L, Pickering D, Loukas A, Sotillo J (2020a) Proteomic analysis of two populations of Schistosoma mansoni-derived extracellular vesicles: $15 \mathrm{k}$ pellet and $120 \mathrm{k}$ pellet vesicles. Mol Biochem Parasitol 236:111264. https://doi.org/10.1016/j.molbiopara.2020.111264 
Kifle DW, Chaiyadet S, Waardenberg AJ, Wise I, Cooper M, Becker L, Doolan DL, Laha T, Sotillo J, Pearson MS, Loukas A (2020b) Uptake of Schistosoma mansoni extracellular vesicles by human endothelial and monocytic cell lines and impact on vascular endothelial cell gene expression. Int J Parasitol 50:685-696. https://doi.org/10.1016/j.ijpara.2020.05.005

Kikuchi Y, Takai T, Kuhara T, Ota M, Kato T, Hatanaka H, Ichikawa S, Tokura T, Akiba H, Mitsuishi K, Ikeda S, Okumura K, Ogawa $\mathrm{H}$ (2006) Crucial commitment of proteolytic activity of a purified recombinant major house dust mite allergen Der p1 to sensitization toward $\mathrm{IgE}$ and $\operatorname{IgG}$ responses. J Immunol 177:1609-1617. https://doi.org/10.4049/jimmunol.177.3.1609

Kittur N, Binder S, Campbell CH, King CH, Kinung'hi S, Olsen A, Magnussen P, Colley DG (2017) Defining persistent hotspots: areas that fail to decrease meaningfully in prevalence after multiple years of mass drug administration with praziquantel for control of schistosomiasis. Am J Trop Med Hyg 97:1810-1817. https://doi.org/10.4269/ajtmh.19-0193

Knudsen GM, Medzihradszky KF, Lim KC, Hansell E, McKerrow JH (2005) Proteomic analysis of Schistosoma mansoni cercarial secretions. Mol Cell Proteom 4:1862-1875. https://doi.org/10 .1074/mcp.M500097-MCP200

Kojima S, Janecharut T, Hata H, Niimura M (1987a) Role of a mouse monoclonal IgE antibody in passive transfer of immunity to Schistosoma japonicum infection. Mem Inst Oswaldo Cruz 82:237-241. https://doi.org/10.1590/s0074-02761987000800045

Kojima S, Niimura M, Kanazawa T (1987b) Production and properties of a mouse monoclonal IgE antibody to Schistsoma japonicum. J Immunol 139:2044-2049

Koster B, Hall MRT, Strand M (1993) Schistosoma mansoni: immuno-reactivity of human sera with the surface antigen Sm23. Exp Parasitol 77:282-294. https://doi.org/10. 1006/expr.1993.1086

Krautz-Peterson G, Debatis M, Tremblay JM, Oliveira SC, Da'dara AA, Skelly PJ, Shoemaker CB (2017) Schistosoma mansoni infection of mice, rats and humans elicits a strong antibody response to a limited number of reduction-sensitive epitopes on five major tegumental membrane proteins. PloS Negl Trop Dis 11:e0005306. https://doi.org/10.1371/journal.pntd.0005306

Krautz-Peterson G, Simoes M, Faghiri Z, Ndegwa D, Oliveira G, Shoemaker CB, Skelly PJ (2010) Suppressing glucose transporter gene expression in schistosomes impairs parasite feeding and decreases survival in the mammalian host. PloS Pathog 6:e1000932. https://doi.org/10.1371/journal.ppat.1000932

Kumagai T, Maruyama H, Hato M, Ohmae H, Osada Y, Kanazawa T, Ohta N (2005) Schistosoma japonicum: localization of calpain in the penetration glands and secretions of cercariae. Exp Parasitol 109:53-57. https://doi.org/10.1016/j.exppara.2004.11.001

Kura K, Hardwick RJ, Truscott JE, Toor J, Hollingsworth TD, Anderson RM (2020) The impact of mass drug administration onSchistosoma haematobium infection: What is required to achieve morbidity control and elimination? Parasit Vectors 13:554. https://doi.org/10.1186/s13071-020-04409-3

Kurtis JD, Jiz MA, Wu H, Olveda R, Jarilla B (2015) Development of paramyosin as a vaccine candidate for schistosomiasis. Front Immunol 6:347. https://doi.org/10.3389/fimmu.2015.00347

La Flamme AC, Patton EA, Pearce EJ (2001) Role of gamma interferon in the pathogenesis of severe schistosomiasis in interleukin-4-deficient mice. Infect Immun 69:7445-7452. https://doi.org/10.1128/IAI.69.12.7445-7452.2001

Lanar DE, Pearce EJ, James SL, Sher A (1986) Identification of paramyosin as schistosome antigen recognized by intradermally vaccinated mice. Science 234:593-596. https://doi.org/10.1126 /science.3094144

Le L, Molehin AJ, Nash S, Sennoune SR, Ahmad G, Torben W, Zhang W, Siddiqui AA (2018) Schistosoma egg-induced liver pathology resolution by $\mathrm{Sm}$-p80-basedschistosomiasis vaccine in baboons. Pathology 50:442-449. https://doi.org/10.1016/j .pathol.2018.01.004

Lebel-Binay S, Lagaudriere C, Fradelizi D, Conjeaud H (1995) CD82, tetra-span-transmembrane protein, is a regulated transducing molecule on U937 monocytic cell line. J Leukoc Biol 57:956-963. https://doi.org/10.1002/jlb.57.6.956

Leenstra T, Acosta LP, Wu HW, Langdon GC, Solomon JS, Manalo DL, Su L, Jiz M, Jarilla B, Pablo AO, McGarvey ST (2006) T-helper-2 cytokine responses to $\mathrm{Sj} 97$ predict resistance to reinfection with Schistosoma japonicum. Infect Immun 74:370-381. https://doi.org/10.1128/IAI.74.1.370-381.2006

Lett E, Klopfenstein C, Klein JP, Scholler M, Wachsmann D (1995) Mucosal immunogenicity of polysaccharides conjugated to a peptide or multiple-antigen peptide containing T- and B-cell epitopes. Infect Immun 63:2645-2651. https://doi.org/10.1128 /IAI.63.7.2645-2651

Li GF, Wang Y, Zhang Z, Wang XJ, Ji MJ, Zhu X, Liu F, Cai XP, Wu HW, Wu GL (2005) Identification of immunodominant Th1-type T cell epitopes from Schistosoma japonicum $28 \mathrm{kDa}$ glutathioneS-transferase, a vaccine candidate. Acta Biochim Biophys Sin 37:751-758. https://doi.org/10.1111/j.1745-7270.2005.00111.x

Liao Q, Yuan X, Xiao H, Liu C, Lv Z, Zhao Y, Wu Z (2011) Identifying Schistosoma japonicum excretory/secretory proteins and their interactions with host immune system. PLoS ONE 6:e23786. https://doi.org/10.1371/journal.pone.0023786

Loukas A, Tran M, Pearson MS (2007) Schistosome membrane proteins as vaccines. Int J Parasitol 37:257-263. https://doi.org/ 10.1016/j.ijpara.2006.12.001

LoVerde PT (2019) Schistosomiasis. Adv Exp Med Biol 1154:45-70. https://doi.org/10.1007/978-3-030-18616-6_3

LoVerde PT, Carvalho-Querioz C, Cook R (2004) Vaccination with antioxidant enzymes confer protective immunity against challenge infection with Schistosoma mansoni. Mem Inst Oswaldo Cruz 99:37-43. https://doi.org/10.1590/s0074-02762004000 900007

Luna EJA, Campos SRSLDC (2020) Vaccine development against neglected tropical diseases. Cad Saude Publica 36(Suppl 2):e00215720. https://doi.org/10.1590/0102-311X00215720

Mahajan B, Berzofsky JA, Boykins RA, Majam V, Zheng H, Chattopadhyay R, de la Vega P, Moch JK, Haynes JD, Belyakov IM, Nakhasi HL, Kumar S (2010) Multiple antigen peptide vaccines against Plasmodium falciparum malaria. Infect Immun 78:4613-4624. https://doi.org/10.1128/IAI.00533-10

Mahana NA (2007) Human and murine immune responses to the Schistosoma mansoni glucose transporter. Ph.D Disseration. Faculty of Science, Cairo University. pp 240

Martins VP, Pinheiro CS, Figueiredo BC, de Assis NR, Morais SB, Caliari MV, Azevedo V, Castro-Borges W, Wilson RA, Oliveira SC (2012) Vaccination with enzymatically cleaved GPI-anchored proteins from schistosoma mansoni induces protection against challenge infection. Clin Dev Immunol 2012:962538. https://doi.org/10.1155/2012/962538

Martins VP, Morais SB, Pinheiro CS, de Assis NR, Figueiredo BC, Ricci ND, Alves-Silva J, Caliari MV, Oliveira SC (2014) Sm10.3, a member of the micro-exon gene 4 (MEG-4) family, induces erythrocyte agglutination in vitro and partially protects vaccinated mice against Schistosoma mansoni infection. PloS Negl Trop Dis 8:e2750. https://doi.org/10.1371/journal. pntd.0002750

McManus DP (1999) The search for a vaccine against schistosomiasis-a difficult path but an achievable goal. Immunol Rev 171:149-161. https://doi.org/10.1111/j.1600-065x.1999.tb01346.x

McManus DP, Bergquist R, Cail P, Ranasinghe S, Tebeje BM, You H (2020) Schistosomiasis from immunopathology to vaccines. 
Semin Immunopathol 42:355-371. https://doi.org/10.1007/ s00281-020-00789-x

McManus DP, Loukas A (2008) Current status of vaccines for schistosomiasis. Clin Microbiol Rev 21:225-242. https://doi.org/10.1128/CMR.00046-07

McManus DP, Wong JY, Zhou J, Cai C, Zeng Q, Smyth D, Li Y, Kalinna BH, Duke MJ, Yi X (2001) Recombinant paramyosin (rec-Sj-97) tested for immunogenicity and vaccine efficacy against Schistosoma japonicum in mice and water buffaloes. Vaccine 20:870-878. https://doi.org/10.1016/s0264-410x (01)00405-4

McNair AT, Dissous C, Duvaux-Miret O, Capron A (1993) Cloning and characterisation of the gene encoding the $28 \mathrm{kDa}$ glutathione S-transferase of Schistosoma mansoni. Gene 124:245-249. https://doi.org/10.1016/0378-1119(93)90400-w

Mei H, LoVerde PT (1997) Schistosoma mansoni: the developmental regulation and immunolocalization of antioxidant enzymes. Exp Parasitol 86:69-78. https://doi.org/10.1006/expr.1997.4150

Mekonnen GG, Tedla BA, Pickering D, Becker L, Wang L, Zhan B, Bottazzi ME, Loukas A, Sotillo J, Pearson MS (2020) Schistosoma haematobiumextracellular vesicle proteins confer protection in a heterologous model of schistosomiasis. Vaccines 8:416. https://doi.org/10.3390/vaccines8030416

Mezo G, Kajtar J, Nagy I, Szekerke M, Hudecz F (1997) Carrier design: synthesis ad conformational studies of poly (L- Lysine) based branched polypeptides with hydroxyl group in the side chains. Biopolymers 42:719-730

Migliardo F, Tallima H, El Ridi R (2014) Is there a sphingomyelinbased hydrogen bond barrier at the mammalian host-schistosome parasite interface? Cell Biochem Biophys 68:359-367. https://doi.org/10.1007/s12013-013-9716-3

Mkojii GM, Smith JM, Prichard RK (1988) Anti-oxidant systems in Schistosoma mansoni: correlation between susceptibility to oxidant killing and the levels of scavengers of hydrogen per oxide and oxygen free radicals. Int J Parasitol 18:661-666. https://doi.org/10.1016/0020-7519(88)90102-6

Mo AX, Agosti JM, Walson JL, Hall BF, Gordon L (2014) Schistosomiasis elimination strategies and potential role of a vaccine in achieving global health goals. Am J Trop Med Hyg 90:54-60. https://doi.org/10.4269/ajtmh.13-0467

Molehin AJ (2020) Schistosomiasis vaccine development: update on human clinical trials. J Biomed Sci 27:28. https://doi.org/10.1186/s12929-020-0621-y

Molehin AJ, Sennoune SR, Zhang W, Rojo JU, Siddiqui AJ, Herrera KA, Johnson L, Sudduth J, May J, Siddiqui AA (2017) Crossspecies prophylactic efficacy of Sm-p80-based vaccine and intracellular localization of Sm-p80/Sm-p80 ortholog proteins during development in Schistosoma mansoni, Schistosoma japonicum, andSchistosoma haematobium. Parasitol Res 116:3175-3188. https://doi.org/10.1007/s00436-017-5634-4

Moser D, Tendler M, Griffiths G, Klinkert MQ (1991) A 14-kDa Schistosoma mansoni polypeptide is homologous to a gene family of fatty acid binding proteins. J Biol Chem 266:8447-8454

Mossallam SF, Amer EI, Ewaisha RE, Khalil AM, Aboushleib HM, Bahey-El-Din M (2015) Fusion protein comprised of the two schistosomal antigens, Sm14 and Sm29, provides significant protection against Schistosoma mansoni in murine infection model. BMC Infect Dis 15:147. https://doi.org/10.1186/ s12879-015-0906-z

Nara T, Tanabe K, Mahakunkijcharoen Y, Osada Y, Matsumoto N, Kita K, Kojima S (1997) The B cell epitope of paramyosin recognized by a protective monoclonal IgE antibody to Schistosoma japonicum. Vaccine 15:79-84. https://doi.org/10.1016/ s0264-410x(96)00100-4
Nare B, Smith JM, Prichard RK (1990) Schistosoma mansoni: levels of antioxidants and resistance to oxidants increase during development. Exp Parasitol 70:389-397. https://doi.org/10.10 16/0014-4894(90)90122-s

Nascimento EJ, Amorim RV, Cavalcanti A, Alves VF, Nakazawa M, Pereira VR, Lucena-Silva N (2007) Assessment of a DNA vaccine encoding an anchored- glycosylphosphatidylinositol tegumental antigen complexed to protamine sulphate on immune protection against murine schistosomiasis. Mem Inst Oswaldo Cruz 102:21-27. https://doi.org/10.1590/s0074-0276200 7000100003

Nawaratna SS, Gobert GN, Willis C, Mulvenna J, Hofmann A, McManus DP, Jones MK (2015) Lysosome-associated membrane glycoprotein (LAMP) - preliminary study on a hidden antigen target for vaccination against schistosomiasis. Sci Rep 5:15069. https://doi.org/10.1038/srep15069

Noya O, Alarcon de Noya B, Guzman F, Bermudez H (2003a) Immunogenicity of Sm32 synthetic peptides derived from the Schistsoma mansoni adult worm. Immunol Lett 88:211-219. https://doi.org/10.1016/s0165-2478(03)00086-5

Noya O, Patarroyo ME, Guzmán F, de Noya BA (2003b) Immunodiagnosis of parasitic diseases with synthetic peptides. Curr Protein Pept Sci. https://doi.org/10.2174/1389203033487153

Ohta N, Kumagai T, Maruyama H, Yoshida A, He Y, Zhang R (2004) Research on calpain of Schistosoma japonicum as a vaccine candidate. Parasitol Int 53:175-181. https://doi.org/10.1016 /j.parint.2004.01.007

Oligino LD, Percy AJ, Harn DA (1988) Purification and immunochemical characterization of a 22 kilodalton surface antigen from Schistosoma mansoni. Mol Biochem Parasitol 28:95-103. https://doi.org/10.1016/0166-6851(88)90056-4

Oliveira SC, Figueiredo BC, Cardoso LS, Carvalho EM (2016) A double-edged sword: Schistosoma mansoni Sm29 regulates both Th1 and Th2 responses in inflammatory mucosal diseases. Mucosal Immunol 9:1366-1371. https://doi.org/10.103 8/mi.2016.69

Othman A, El Ridi R (2014) Schistosomiasis. In: Bruschi F (ed) Helminth infections and their impact on global public health. Springer, New York, pp 49-92

Pacifico LG, Fonseca CT, Barsanate MM, Cardoso LS, Araujo MI, Oliveria SC (2006a) Aluminum hydroxide associated to schistosoma mansoni $22.6 \mathrm{KDa}$ protein abrogates partial protection against experimental infection but not alter interleukin -10 production. Mem Inst Oswaldo Cruz 101:365-368. https://doi.org/10.1590/s0074-02762006000900060

Pacifico LG, Fonseca CT, Chiari L, Oliveria SC (2006b) Immunization with schistosoma mansoni $22.6 \mathrm{KDa}$ antigen induces partial protection against experimental infection in a recombinant protein form but not as DNA vaccine. Immunobiology 211:97-104. https://doi.org/10.1016/j.imbio.2005.06.004

Patarroyo ME, Romero P, Torres ML, Moreno A, Martinez A, Rodriguez R, Guzman F, Cabazas E (1987) Induction of protective immunity against experimental infection with malaria using synthetic peptides. Nature 328:629-632. https://doi.org/10. 1038/328629a0

Pearce EJ, James SL, Dalton J, Barrall A, Ramos C, Strand M, Sher A (1986) Immunochemical characterization and purification of Sm97, a Schistosoma mansoni antigen monospecifically recognized by antibodies from mice protectively immunized with a nonliving vaccine. J Immunol 137:3593-3600

Pearce EJ, James SL, Hieny S, Lanar DE, Sher A (1988) Induction of protective immunity against Schistosoma mansoni by vaccination with schistosome paramyosin (Sm97), a non-surface parasite antigen. Proc Natl Acad Sci USA 85:5678-5682. https://doi.org/10.1073/pnas.85.15.5678 
Pearson MS, Becker L, Driguez P, Young ND, Gaze S, Mendes T, Li XH, Doolan DL, Midzi N, Mduluza T, McManus DP, Wilson RA, Bethony JM, Nausch N, Mutapi F, Felgner PL, Loukas A (2015) Of monkeys and men: immune micprofiling of sera from humans and non-human primates resistant to schistosomiasis reveals novel potential vaccine candidates. Front Immunol 6:213. https://doi.org/10.3389/fimmu.2015.00213

Perera DJ, Hassan AS, Jia Y, Ricciardi A, McCluskie MJ, Weeratna RD, Ndao M (2020) Adjuvanted Schistosoma mansoni-cathepsin B with sulfated lactosyl archaeol archaeosomes or addavax provides protection in a pre-clinical schistosomiasis model. Front Immunol 11:605288. https://doi.org/10.3389/fimmu. 2020.605288

Pinheiro CS, Ribeiro APD, Cardoso FC, Martins VP, Figueiredo BC, de Assis NR, Morais SB, Caliari MV, Loukas A, Oliveira SC (2014) A multivalent chimeric vaccine composed of Schistosoma mansoni Sm TSP-2 and Sm29 was able to induce protection against infection in mice. Parasite Immunol 36:303-312. https://doi.org/10.1111/pim.12118

Pirovich DB, Da'dara AA, Skelly PJ (2019) Why do intravascular schistosomes coat themselves in glycolytic enzymes? BioEssays 41:e1900103. https://doi.org/10.1002/bies.201900103

Pirovich DB, Da'dara AA, Skelly PJ (2020) Schistosoma mansoni glyceraldehyde-3-phosphate dehydrogenase enhances formation of the blood-clot lysis protein plasmin. Biol Open 9:bio050385. https://doi.org/10.1242/bio.050385

Pluchino S, Smith JA (2019) Explicating exosomes: reclassifying the rising stars of intercellular communication. Cell 177:225-227. https://doi.org/10.1016/j.cell.2019.03.020

Pollock KG, McNeil KS, Mottram JC, Lyons RE, Brewer JM, Scott P, Coombs GH, Alexander J (2003) The Leishmania mexicana cysteine protease, CPB2.8, induces potent Th2 responses. J Immunol 170:1746-1753. https://doi.org/10.4049/jimmunol .170 .4 .1746

Price AE, Liang HE, Sullivan BM, Reinhardt RL, Eisley CJ, Erle DJ, Locksley RM (2010) Systemically dispersed innate IL-13expressing cells in type 2 immunity. Proc Natl Acad Sci USA 107:11489-11494. https://doi.org/10.1073/pnas.100398810

Purcell AW, McCluskey J, Rossjohn J (2007) More than one reason to rethink the use of peptides in vaccine design. Nat Rev Drug Discov 6:404-414. https://doi.org/10.1038/nrd2224

Rahmani A, Baee M, Rostamtabar M, Karkhah A, Alizadeh S, Tourani M, Nouri HR (2019) Development of a conserved chimeric vaccine based on helper T-cell and CTL epitopes for induction of strong immune response againstSchistosoma mansoniusingimmunoinformatics approaches. Int J Biol Macromol 141:125-136. https://doi.org/10.1016/j.ijbiomac.2019.08.259

Reis EAG, Mauadi Carmo TA, Athanazio R, Reis MG, Harn DA (2008) Schistosoma mansoni triose phosphate isomerase peptide MAP4 is able to trigger naive donor immune response towards a type-1 cytokine profile. Scand J Immunol 68:169-176. https://doi.org/10.1111/j.1365-3083.2008.02131.x

Reynolds SR, Shoemaker CB, Harn DA (1992) T and B cell epitope mapping of SM23, an integral membrane protein of Schistosoma mansoni. J Immunol 149:3995-4001

Ricciardi A, Dalton JP, Ndao M (2015) Evaluation of the immune response and protective efficacy of Schistosoma mansoni cathepsin $\mathrm{B}$ in mice using $\mathrm{CpG}$ dinucleotides as adjuvant. Vaccine 33:346-353. https://doi.org/10.1016/j.vaccine.2014 .11 .016

Ricciardi A, Visitsunthorn K, Dalton JP, Ndao M (2016) A vaccine consisting of Schistosoma mansoni cathepsin B formulated in Montanide ISA 720 VG induces high level protection against murine schistosomiasis. BMC Infect Dis 16:112. https://doi.org 10.1186/s12879-016-1444-z
Riveau G, Deplanque D, Remoue F, Schacht AM, Vodougnon H, Capron M, Thiry M, Martial J, Libersa C, Capron A (2012) Safety and immunogenicity of rSh28GST antigen in humans:phase 1 randomized clinical study of a vaccine candidate against urinary schistosomiasis. PloS Negl Trop Dis 6:e1704. https://doi.org/10.1371/journal.pntd.0001704

Riveau G, Schacht AM, Dompnier JP, Deplanque D, Seck M, Waucquier N, Senghor S, Delcroix-Genete D, Hermann E, IdrisKhodja N, Levy-Marchal C, Capron M, Capron A (2018) Safety and efficacy of the rSh28GSTurinary schistosomiasis vaccine: a phase 3 randomized, controlled trial in Senegalese children. PloS Negl Trop Dis 12:e0006968. https://doi.org/10.137 1/journal.pntd.0006968

Roche L, Dowd AJ, Tort J, McGonigle S, MacSweeney A, Curley GP, Ryan T, Dalton JP (1997) Functional expression of Fasciola hepatica cathepsin L1 in Saccharomyces cerevisiae. Eur J Biochem 245:373-380. https://doi.org/10.1111/j.1432-1033 .1997.t01-1-00373.x

Rogers MV, Davern KM, Smythe JA, Mitchell GF (1988) lmmunoblotting analysis of the major integral membrane protein antigens of Schistosoma japonicum. Mol Biochem Parasitol 29:77-87. https://doi.org/10.1016/0166-6851(88)90122-3

Ross AGP, Bartley PB, Sleigh AC, Olds GR, Li Y, Williams GM, McManus DP (2002) Schistosomiasis. N Engl J Med 346:1212-1220. https://doi.org/10.1056/NEJMra012396

Ross AG, Olveda RM, Chy D, Olveda DU, Li Y, Harn DA, Gray DJ, McManus DP, Tallo V, Chau TN, Williams GM (2015) Can mass drug administration lead to the sustainable control of schistosomiasis? J Infect Dis 211:283-289. https://doi.org/ 10.1093/infdis/jiu416

Sahay B, Aranyos AM, Mishra M, McAvoy AC, Martin MM, Pu R, Shiomitsu S, Shiomitsu K, Dark MJ, Sanou MP, Roff SR, Rathore MH, Yamamoto JK (2019) Immunogenicity and efficacy of a novel multi-antigenic peptide vaccine based on cross-reactivity between feline and human immunodeficiency viruses. Viruses 11:136. https://doi.org/10.3390/v11020136

Samoil V, Dagenais M, Ganapathy V, Aldridge J, Glebov A, Jardim A, Ribeiro P (2018) Vesicle-based secretion in schistosomes: analysis of protein and microRNA (miRNA) content of 650 exosome-like vesicles derived from Schistosoma mansoni. Sci Rep 8:3286. https://doi.org/10.1038/s41598-018-21587-4

Santini-Oliveira M, Coler RN, Parra J, Veloso V, Jayashankar L, Pinto PM, Ciol MA, Bergquist R, Reed SG, Tendler M (2016) Schistosomiasis vaccine candidate Sm14/GLA-SE: phase 1 safety and immunogenicity clinical trial in healthy, male adults. Vaccine 34:586-594. https://doi.org/10.1016/j.vaccine.2015 .10 .027

Saule P, Vicogne J, Delacre M, Macia L, Tailleux A, Dissous C, Auriault C, Wolowczuk I (2005) Host glucose metabolism mediates T4 and IL-7 action on Schistosoma mansoni development. J Parasitol 91:737-744. https://doi.org/10.1645/GE-3402.1

Schulte L, Lovas E, Green K, Mulvenna J, Gobert GN, Morgan G, Jones MK (2013) Tetraspanin-2 localisation in high pressure frozen and freeze-substituted Schistosoma mansoni adult males reveals its distribution in membranes of tegumentary vesicles. Int J Parasitol 43:785-793. https://doi.org/10.1016/j.ijpara .2013 .04 .003

Shalaby KA, Yin L, Thakur A, Christen L, Niles EG, Loverde PT (2003) Protection against Schistosoma mansoni utilizing DNA vaccination with genes encoding $\mathrm{Cu} / \mathrm{Zn}$ cytosolic superoxide dismutase, signal peptide-containing superoxide dismutase and glutathione peroxidase enzymes. Vaccine 22:130-136. https://doi.org/10.1016/s0264-410x(03)00535-8

Shen HD, Lin WL, Tam MF, Wang SR, Tsai JJ, Chou H, Han SH (1998) Alkaline serine proteinase: a major allergen of Aspergillus oryzae and its crossreactivity with Penicillium citrinum. Int 
Arch Allerg Immunol 116:29-35. https://doi.org/10.1159/000023921

Sher A, Pearce E, Hieny S, James S (1986) Induction of protective immunity against Schistosoma mansoni by a nonliving vaccine. IV. Fractionation and antigenic properties of a soluble adult worm immunoprophylactic activity. J Immunol 136:3878-3883

Shreewastav RK, Ali R, Uppada JB, Rao DN (2012) Cell mediated immune response to epitopic MAP (multiple antigen peptide) construct of L c r V antigen of Yersinia pestisinmurine model. Cell Immunol 278:55-62. https://doi.org/10.1016/ j.cellimm.2012.07.002

Siddiqui AA, Siddiqui SZ (2017) Sm-p80-based schistosomiasis vaccine: preparation for human clinical trials. Trends Parasitol 33:194-201. https://doi.org/10.1016/j.pt.2016.10.010

Siddiqui AA, Zhou Y, Podesta RB, Karcz SR, Tognon CE, Strejan GH, Dekaban GA, Clarke MW (1993) Characterization of Ca (2+)-dependent neutral protease (calpain) from human blood flukes, Schistosoma mansoni. Biochim Biophys Acta 1181:37-44. https://doi.org/10.1016/0925-4439(93)90087-h

Siddiqui AA, Phillips T, Charest H, Podesta RB, Quinlin ML, Pinkston JR, Lloyd JD, Pompa J, Villalovos RM, Paz M (2003a) Enhancement of Sm-p80 (large subunit of calpain) induced protective immunity against Schistosoma mansonithrough codelivery of interleukin-2 and interleukin-12 in a DNA vaccine formulation. Vaccine 21:2882-2889. https://doi.org/10.1016/ s0264-410x(03)00159-2

Siddiqui AA, Phillips T, Charest H, Podesta RB, Quinlin ML, Pinkston JR, Lloyd JD, Paz M, Villalovos RM, Pompa J (2003b) Induction of protective immunity against Schistosoma mansoni via DNA priming and boosting with the large subunit of calpain (Smp80): adjuvant effects of granulocyte-macrophage colonystimulating factor and interleukin-4. Infect Immun 71:3844-3851. https://doi.org/10.1016/s0264-410x(03)00159-2

Siddiqui AA, Pinkston JR, Quinlin ML, Kavikondala V, RewersFelkins KA, Phillips T, Pompa J (2005a) Characterization of protective immunity induced against Schistosoma mansonivia DNA priming with the large subunit of calpain (Sm-p80) in the presence of genetic adjuvants. Parasite 12:3-8. https://doi.org/10 $.1051 /$ parasite/2005121003

Siddiqui AJ, Molehin AJ, Zhang W, Ganapathy PK, Kim E, Rojo JU, Redman WK et al (2018) Sm-p80-based vaccine trial in baboons: efficacy when mimicking natural conditions of chronic disease, praziquantel therapy, immunization, and Schistosoma mansoni re-encounter. Ann NY Acad Sci 1425:19-37

Siracusa MC, Saenz SA, Hill DA, Kim BS, Headley MB, Doering TA et al (2011) TSLP promotes interleukin-3-independent basophil haematopoiesis and type 2 inflammation. Nature 477:229-233. https://doi.org/10.1038/nature10329

Skelly P, Tielens AG, Shoemaker C (1998) Glucose transport and metabolism in mammalian-stage schistosomes. Parasitol Today 14:402-406. https://doi.org/10.1016/s0169-4758(98)01319-2

Smyth D, McManus DP, Smout MJ, Laha T, Zhang W, Loukas A (2003) Isolation of cDNAs encoding secreted and transmembrane proteins from Schistosoma mansoni by a signal sequence traps method. Infect Immun 71:2548-2554. https://doi.org/ 10.1128/iai.71.5.2548-2554.2003

Soisson LM, Masterson CP, Tom TD, McNally MT, Lowell GH, Strand M (1992) Induction of protective immunity in mice using a $62-\mathrm{kDa}$ recombinant fragment of a Schistosoma mansoni surface antigen. J Immunol 149:3612-3620

Soisson LA, Reid GDF, Farah IO, Nyindo M, Strand M (1993) Protective immunity in baboons vaccinated with a recombinant antigen or radiation-attenuated cercariae of Schistsoma mansoni is antibody-dependent. J Immunol 151:4782-4789
Sokol CL, Barton GM, Farr AG, Medzhitov R (2008) A mechanism for the initiation of allergen-induced t helper type 2 responses. Nat Immunol 9:310-318. https://doi.org/10.1038/ni1558

Soloviova K, Fox EC, Dalton JP, Caffrey CR, Davies SJ (2019) A secreted schistosome cathepsin B1 cysteine protease and acute schistosome infection induce a transient $\mathrm{T}$ helper 17 response. PloS Negl Trop Dis 13:e0007070. https://doi.org/10.1371 /journal.pntd.0007070

Sotillo J, Pearson M, Becker L, Mulvenna J, Loukas A (2015) A quantitative proteomic analysis of the tegumental proteins from Schistosoma mansoni schistosomula reveals novel potential therapeutic targets. Int J Parasitol 45:505-516. https://doi.org/ 10.1016/j.ijpara.2015.09.002

Sotillo J, Pearson M, Potriquet J, Becker L, Pickering D, Mulvenna, Loukas A (2016) Extracellular vesicles secreted by Schistosoma mansonicontain protein vaccine candidates. Int $\mathrm{J}$ Parasitol 46:1-5. https://doi.org/10.1016/j.ijpara.2015.09.002

Stephenson RJ, Toth I, Liang J, Mangat A, McManus DP, You H (2016) Identification of host insulin binding sites on Schistosoma japonicum insulin receptors. PLoS ONE 11:e0159704. https://doi.org/10.1371/journal.pone.0159704

Street M, Coulson PS, Sadler C, Warnock LJ, McLaughlin D, Bluethmann H, Wilson RA (1999) TNF is essential for the cellmediated protective immunity induced by the radiation-attenuated schistosome vaccine. J Immunol 163:4489-4494

Swain MT, Larkin DM, Caffrey CR, Davies SJ, Loukas A, Skelly PJ, Hoffmann KF (2011) Schistosoma comparative genomics: integrating genome structure, parasite biology and anthelmintic discovery. Trends Parasitol 27:555-564. https://doi.org/10. 1016/j.pt.2011.09.003

Tallima H, Montash M, Veprek P, Velek J, Jezek J, El Ridi R (2003) Differences in immunogenicity and vaccine potential of peptides from Schistosoma mansoni glyceraldehyde 3-phosphate dehydrogenase. Vaccine 21:3290-3300. https://doi.org/10.1016/ s0264-410x(03)00180-4

Tallima H, El Ridi R (2008) Schistosoma mansoni glyceraldehyde 3-phosphate dehydrogenase is a lung-stage schistosomula surface membrane antigen. Folia Parasitol 55:180-186. https://doi.org/10.14411/fp.2008.025

Tallima H, Dalton JP, El Ridi R (2015) Induction of protective immune responses against Schistosomiasis haematobium in hamsters and mice using cysteine peptidase-based vaccine. Front Immunol 6:130. https://doi.org/10.3389/fimmu.2015.00130

Tallima H, Abou El Dahab M, Kareem S, Dalton JP, El Ridi R (2017a) Protection against Schistosoma haematobium infection in hamsters by immunization with Schistosoma mansonigutderived cysteine peptidases, SmCB1 and SmCL3. Vaccine 135:6977-6983. https://doi.org/10.1016/j.vaccine.2017.10.069

Tallima H, Dvořák J, Kareem S, Abou El Dahab M, Abdel Aziz N, Dalton JP, El Ridi R (2017b) Protective immune responses against Schistosoma mansoni infection by immunization with functionally active gut-derived cysteine peptidases alone and in combination with glyceraldehyde 3-phosphate dehydrogenase. PLoS Negl Trop Dis 11:e0005443. https://doi.org/10.1371/ journal.pntd.0005443

Tallima H, Abou El Dahab M, El Ridi R (2019) Role of T lymphocytes and papain enzymatic activity in the protection induced by the cysteine protease against Schistosoma mansoni in mice. J Adv Res 17:73-84. https://doi.org/10.1016/ j.jare.2018.12.008

Tallima H, Abou El Dahab M, El Ridi R (2020a) Specific antibodies and arachidonic acid mediate the protection induced by the Schistosoma mansoni cysteine peptidase-based vaccine in mice. Vaccines 8:682. https://doi.org/10.3390/vaccines8040682

Tallima H, Hanna VS, El Ridi R (2020b) Arachidonic Acid is a safe and efficacious schistosomicide, and an endoschistosomicide in 
natural and experimental infections, and cysteine peptidase vaccinated hosts. Front Immunol 11:609994. https://doi.org/10. 3389/fimmu.2020.609994

Tam JP (1988) Synthetic peptide vaccine design: synthesis and properties of a high-density multiple antigenic peptide system. Proc Natl Acad Sci USA 85:5409-5413. https://doi.org/10. 1073/pnas.85.15.5409

Tam JP (1995) Synthesis and applications of branched peptides in immunological methods and vaccines. In: Gutte B (ed) Peptides: synthesis, structures, and applications. Acad Press Inc, Cambridge, pp 455-500

Tang CW, Liu SJ, MaYB LL, Guo P, Wang SY, Gao H, Duan QH, Cheng JZ, Dai WX (2008) A multi-gene DNA vaccine encoding non-fusion membrane-anchoring antigen against Schistosoma japonicum. Chin J Parasitol Parasit Dis 26:412-416

Taylor JB, Vidal A, Torpier G, Meyer DJ, Roitsch C, Balloul JM, Southan C, Sondermeyer P, Pemble S, Lecocq JP (1988) The glutathione transferase activity and tissue distribution of a cloned Mr28K protective antigen of Schistosoma mansoni. Eur Mol Biol Org J 7:465-472

Taylor MG, Huggins MC, Shi F, Lin J, Tian E, Ye P, She W, Qian CG, Lin BF, Bickle QD (1998) Production and testing of Schistosoma japonicum candidate vaccine antigens in the natural ovine host. Vaccine 16:1290-1298. https://doi.org/10.1016/ s0264-410x(98)00055-3

Tebeje BM, Harvie M, You H, Loukas A, McManus DP (2016) Schistosomiasis vaccines: Where do we stand? ParasitVectors 9:528. https://doi.org/10.1186/s13071-016-1799-4

Tendler M, Almeida M, Simpson A (2015) Development of the Brazilian anti schistosomiasis vaccine based on the recombinant fatty acid binding protein Sm14 plus GLA-SE adjuvant. Front Immunol 6:218. https://doi.org/10.3389/fimmu.2015.00218

Tendler M, Almeida MS, Vilar MM, Pint PM, Limaverde-Sousa G (2018) Current status of the Sm14/GLA-SE schistosomiasis vaccine: overcoming barriers and paradigms towards the first antiparasitic human (itarian) vaccine. Trop Med Infect Dis 3:121. https://doi.org/10.3390/tropicalmed3040121

Tendler M, Brito CA, Vilar MM, Serra-Freire N, Diogo CM, Almeida MS, Delbem AC, Da Silva JF, Savino W, Garratt RC, Katz N, Simpson AS (1996) A Schistosoma mansoni fatty acid-binding protein, Sm14, is the potential basis of a dual-purpose antihelminth vaccine. Proc Natl Acad Sci USA 93:269-273. https://doi.org/10.1073/pnas.93.1.269

Tendler M, Simpson AJ (2008) The biotechnology-value chain: development of Sm14 as a schistosomiasis vaccine. Acta Trop 108:263-266. https://doi.org/10.1016/j.actatropica.2008.09.002

Tendler M, Vilar MM, Brito CA, Freire NMS, Katz N, Simpson AJG (1995) Vaccination against schistosomiasis and fascioliasis with the new recombinant antigen Sm14: potential basis of a multivalent anti-helminth vaccine? Mem Inst Oswaldo Cruz 90:255-256. https://doi.org/10.1590/s0074-02761995000200022

Torben W, Ahmad G, Zhang W, Nash S, Le L, Karmakar S, Siddiqui AA (2012) Role of antibody dependent cell mediated cytotoxicity (ADCC) in Sm-p80-mediated protection against Schistosoma mansoni. Vaccine 30:6753-6758. https://doi.org/10.1016/ j.vaccine.2012.09.026

Torben W, Ahmad G, Zhang W, Siddiqui AA (2011) Role of antibodies in Sm-p80-mediated protection against Schistosoma mansoni challenge infection in murine and nonhuman primate models. Vaccine 29:2262-2271. https://doi.org/10.1016/ j.vaccine.2011.01.040

Tran MH, Freitas TC, Cooper L, Gaze S, Gatton ML, Jones MK, Lovas E, Pearce EJ, Loukas A (2010) Suppression of mRNAs encoding tegument tetraspanins from schistosoma mansoni results in impaired tegument turnover. PloS Pathog 6:e1000840. https://doi.org/10.1371/journal.ppat.1000840
Tran MH, Pearson MS, Bethony JM, Smyth DJ, Jones MK, Duke M, Don TA, McManus DP, Correa-Oliveira R, Loukas A (2006) Tetraspanins on the surface of Schistosoma mansoni are protective antigens against schistosomiasis. Nat Med 12:835-840. https://doi.org/10.1038/nm1430

Tsikaris V, Sakarellos-Daitsiotis M, Tzovaras D, Sakarellos C, Orlewski P, Cung MT, Marraud M (1996a) Isomerization of the Xaa-Pro peptide bond induced by ionic interactions of arginine. Biopolymers 38:291-293

Tsikaris V, Sakarellos C, Sakarellos-Daitsiotis M, Orlewski P, Marraud M, Cung MT, Vatzaki E, Tzartos S (1996b) Construction and application of a new class of sequential oligopeptide carriers (SOCn) for multiple anchoring of antigenic peptidesapplication to the acetylcholine receptor (AChR) main immunogenic region. Int J Biol Macromol 19:195-205. https://doi.org/10 .1016/0141-8130(96)01128-2

Tsuji N (2020) Schistosomiasis and hookworm infection in humans: disease burden, pathobiology and anthelmintic vaccines. Parasitol Int 75:102051. https://doi.org/10.1016/j.parint.2020.102051

Tucker DF, Sullivan JT, Mattia KA, Fisher CR, Barnes T, Mabila MN, Wilf R, Sulli C, Pitts M, Payne RJ, Hall M, HustonPaterson D, Deng X, Davidson E, Willis SH, Doranz BJ, Chambers R, Rucker JB (2018) Isolation of state-dependent monoclonal antibodies against the 12-transmembrane domain glucose transporter 4 using virus-like particles. Proc Natl Acad Sci U S A 115:E4990-E4999. https://doi.org/10.1073/ pnas. 1716788115

Van Balkom BW, van Gestel RA, Brouwers JF, Krijgsveld J, Tielens AG, Heck AJ, van Hellemond JJ (2005) Mass spectrometric analysis of the Schistosoma mansoni tegumental sub-proteome. J Proteome Res 4:958-966. https://doi.org/10.1021/pr050036w

Varaldo PB, Leite LC, Dias WO, Miyaji EN, Torres FI, Gebara VC, Armoa GR, Campos AS, Matos DC, Winter N, Gicquel B, Vilar MM, McFadden J, Almeida MS, Tendler M, McIntosh D (2004) Recombinant Mycobacterium bovis BCG expressing the Sm14 antigen of Schistosoma mansoni protects mice from cercarial challenge. Infect Immun 72:3336-3343. https://doi.org/10 .1128/IAI.72.6.3336-3343.2004

Veprek P, Jezek AJ, Velek J, Tallima H, Montash M, El Ridi R (2004) Peptides and multiple antigen peptides from Schistsoma mansoniglyceraldehyde 3-phosphate dehydrogenase: preparation, immunogenicity and immunoprotective capacity in C57BL/6 mice. J Peptide Sci 10:350-362. https://doi.org/10.1002/psc.550

Vicogne J, Cailliau K, Tulasne D, Browaeys E, Yan YT, Fafeur V, Vilain JP, Legrand D, Trolet J, Dissous C (2004) Conservation of epidermal growth factor receptor function in the human parasitic helminth Schistosoma mansoni. J Biol Chem 279:37407-37414. https://doi.org/10.1074/jbc.M313738200

Wang Q, Da'dara AA, Skelly PJ (2017) The human blood parasite Schistosoma mansoni expresses extracellular tegumental calpains that cleave the blood clotting protein fibronectin. Sci Rep 7:12912. https://doi.org/10.1038/s41598-017-13141-5

Wang X, Zhang L, Chi Y, Hoellwarth J, Zhou S, Wen X, Su C (2010) The nature and combination of subunits used in epitope-based Schistosoma japonicum vaccine formulations affect their efficacy. Parasit Vector 3:109. https://doi.org/10.1186/1756 $-3305-3-109$

Wendt G, Zhao L, Chen R, Liu C, O'Donoghue AJ, Caffrey CR, Reese ML, Collins JJ (2020) A single-cell RNA-seq atlas of Schistosoma mansoni identifies a key regulator of blood feeding. Science 369:1644-1649. https://doi.org/10.1126/science .abb7709

Wiegand RE, Mwinzi PN, Montgomery SP, Chan YL, Andiego K, Omedo M, Muchiri G, Ogutu MO, Rawago F, Odiere MR, Karanja DMS, Secor WE (2017) A persistent hotspot of Schistosoma mansoni infection in a five-year randomized trial 
of praziquantel preventative chemotherapy strategies. J Infect Dis 216:1425-1433. https://doi.org/10.1093/infdis/jix496

Wilson RA (2012) Proteomics at the schistosome-mammalian host interface: any prospects for diagnostics or vaccines. Parasitology 139:1178-1194. https://doi.org/10.1017/S0031182012000339

World Health Organization (2019) Schistosomiasis and soil-transmitted helminthiases: numbers of people treated in 2018, Wkly Epidemiol Rec 94:601-612. https://www.who.int/wer/2 019/wer9450/en/

Wright MD, Henkle KJ, Mitchell GF (1990) An immunogenic Mr 23,000 integral membrane protein of Schistosoma mansoni worms that closely resembles a human tumor-associated antigen. J Immunol 144:3195-3200

Wright MD, Melder AM, Davern KM, Mitchell GF (1991) Serologic reactivities of the $23-\mathrm{kDa}$ integral membrane proteins of schistosomes. J Immunol 147:4338-4342

Wu HW, Fu ZQ, Lu K, Pond-Tor S, Meng R, Hong Y, Chu K, Li H, Jiz M, Liu JM, Hou M, Park S, Lin JJ, Kurtis JD (2017) Vaccination with recombinant paramyosin in Montanide ISA206 protects against Schistosoma japonicum infection in water buffalo. Vaccine 35:3409-3415. https://doi.org/10.1016 /j.vaccine.2017.05.007

Xu CB, Verwaerde C, Grzych JM, Fontaine J, Capron A (1991) A monoclonal antibody blocking the Schistosoma mansoni $28 \mathrm{kDa}$ glutathione Stransferase activity reduces female worm fecundity and egg viability. Eur J Immunol 21:1801-1807. https://doi.org/10.1002/eji.183021080

You H, Zhang W, Moertel L, McManus DP, Gobert GN (2009) Transcriptional profiles of adult male and female Schistosoma japonicum in response to insulin reveal increased expression of genes involved in growth and development. Int $\mathrm{J}$ Parasitol 39:1551-1559. https://doi.org/10.1016/j.ijpara.2009.06.006

You H, Zhang W, Jones MK, Gobert GN, Mulvenna J, Rees G, Spanevello M, Blair D, Duke M, Brehm K, McManus DP (2010) Cloning and characterisation of Schistosoma japonicum insulin receptors. PLoS ONE 5:e9868. https://doi.org/10.1371/ journal.pone. 0009868

You H, Gobert GN, Duke MG, Zhang W, Li Y, Jones MK, McManus DP (2012) The insulin receptor is a transmission blocking veterinary vaccine target for zoonotic Schistosoma japonicum. Int J Parasitol 42:801-807. https://doi.org/10.1016/j.i jpara.2012.06.002

You H, Stephenson RJ, Gobert GN, McManus DP (2014) Revisiting glucose uptake and metabolism in schistosomes: new molecular insights for improved schistosomiasis therapies. Front Genet 5:176. https://doi.org/10.3389/fgene.2014.00176
You H, Cai P, Tebeje BM, Li Y, McManus DP (2018) Schistosome vaccines for domestic animals. Trop Med Infect Dis 3:68. https://doi.org/10.3390/tropicalmed3020068

Young ND, Jex AR, Li B, Liu S, Yang L, Xiong Z, Li Y, Cantacessi C, Hall RS, Xu X (2012) Whole genome sequence of Schistosoma haematobium. Nat Genet 44:221-225. https://doi.org/ 10.1038/ng.1065

Zhan B, Beaumier CM, Briggs N, Jones KM, Keegan BP, Bottazzi ME, Hotez PJ (2014) Advancing a multivalent 'Pan-anthelmintic' vaccine against soil-transmitted nematode infections. Expert Rev Vaccines 13:321-331. https://doi.org/10.1586/ 14760584.2014.872035

Zhang R, Yoshida A, Kumagai T, Kawaguchi H, Maruyama H, Suzuki T, Itoh M, El-Malky M, Ohta N (2001) Vaccination with calpain induces a Th1-biased protective immune response against Schistosoma japonicum. Infect Immun 69:386-391. https://doi.org/10.1128/IAI.69.1.386-391.2001

Zhang W, Ahmad G, Le L, Rojo JU, Karmakar S, Tillery KA, Torben W, Damian RT, Wolf RF, White GL, Carey DW, Carter D, Reed SG, Siddiqui AA (2014) Longevity of Sm-p80-specific antibody responses following vaccination with $\mathrm{Sm}-\mathrm{p} 80$ vaccine in mice and baboons and transplacental transfer of Sm-p80-specific antibodies in a baboon. Parasitol Res 113:2239-2250. https://doi.org/10.1007/s00436-014-3879-8

Zhang W, Ahmad G, Molehin AJ, Torben W, Le L, Kim E, Lazarus S, Siddiqui AJ, Carter D, Siddiqui AA (2018a) Schistosoma mansoni antigen Sm-p80: prophylactic efficacy using TLR4 agonist vaccine adjuvant glucopyranosyl lipid an alumin murine and non-human primate models. J Investig Med 66:1124-1132. https://doi.org/10.1136/jim-2018-000786

Zhang W, Ahmad G, Torben W, Noor Z, Le L, Damian RT, Wolf RF, White GL, Chavez-Suarez M, Podesta RB, Kennedy RC, Siddiqui AA (2010) Sm-p80-based DNA vaccine provides baboons with levels of protection against Schistosoma mansoni infection comparable to those achieved by the irradiated cercarial vaccine. J Infect Dis 201:1105-1112. https://doi.org $/ 10.1086 / 651147$

Zhang W, Molehin AJ, Rojo JU, Sudduth J, Ganapathy PK, Kim E, Siddiqui AJ, Freeborn J, Sennoune SR, May J et al (2018b) Smp80-based schistosomiasis vaccine: double-blind preclinical trial in baboons demonstrates comprehensive prophylactic and parasite transmission-blocking efficacy. Ann NY Acad Sci 1425:38-51. https://doi.org/10.1111/nyas. 13942

Publisher's Note Springer Nature remains neutral with regard to jurisdictional claims in published maps and institutional affiliations. 